\title{
Latin, Old English and documentary practice at Worcester from Wærferth to Oswald
}

\author{
ROBERT GALLAGHER AND FRANCESCA TINTI
}

\begin{abstract}
This article analyses the uses of Latin and Old English in the charters of Worcester cathedral, which represents one of the largest and most linguistically interesting of the surviving Anglo-Saxon archives. Specifically focused on the period encompassing the episcopates of Wærferth and Oswald (c. 870 to 992), this survey examines a time of intense administrative activity at Worcester, contemporaneous with significant transformations in the political and cultural life of Anglo-Saxon England more generally. In doing so, this article argues that when writing in either Latin or the vernacular, charter draftsmen responded to a number of variables; language choice did not simply reflect varying levels of literacy. Furthermore, the frequent cases of code-switching found in tenth-century Worcester documents mark this community out as exceptional, suggesting that attitudes towards the interaction between the two languages could vary considerably between institutions.
\end{abstract}

In recent decades charters have been at the forefront of research on the uses of the written word in the early medieval period, attesting to the importance of documentary practice for understanding medieval literary cultures more generally. A particularly rich body of publications has focussed on such material from the Frankish world. ${ }^{1}$ The exploration of Anglo-Saxon charters has been somewhat more limited, despite the fact that they constitute one of the most interesting sets of documentary sources to have survived from the early medieval West. ${ }^{2}$ Indeed, Anglo-Saxon England represents a unique case within the territories of the former Western Roman Empire, since charter production there relied on two different languages, namely Latin and increasingly, as time went by, Old English. Although vernaculars can also be seen to 'bleed through the Latin text' in other parts of Europe, as Patrick Geary put it in 1999, the early date at which this first happens in England and the sheer amount of vernacular contained in Anglo-Saxon charters demonstrate the exceptional status of the Old English language within early medieval documentary culture. ${ }^{3}$ AngloSaxon England has long been known for its thriving tradition of vernacular literature, but a deeper understanding of its bilingual written output and the interplay between Latin and Old English has only begun to emerge in recent years. ${ }^{4}$ Moreover, charters have barely featured in such analyses and

\footnotetext{
${ }^{1}$ See especially R. McKitterick, The Carolingians and the Written Word (Cambridge, 1989); The Uses of Literacy in Early Medieval Europe, ed. R. McKitterick (Cambridge, 1990); M. Innes, 'Memory, Orality and Literacy in an Early Medieval Society', Past \& Present 158 (1998), 3-36; P. J. Geary, 'Land, Language and Memory in Europe 700-1100', Transactions of the Royal Historical Society, 6th ser. 9 (1999), 169-84; A. Rio, Legal Practice and the Written Word in the Early Middle Ages: Frankish Formualae, c. 500-1000, Cambridge Studies in Medieval Life and Thought 4 th ser. 75 (Cambridge, 2009); Documentary Culture and the Laity in the Early Middle Ages, ed. W. Brown, M. Costambeys, M. Innes and A. Kosto (Cambridge, 2013).

${ }^{2}$ For important work on Anglo-Saxon literacy and documentary culture see S. Kelly, 'Anglo-Saxon Lay Society and the Written Word', The Uses of Literacy, ed. McKitterick, pp. 36-62; S. Keynes, 'Royal Government and the Written Word in Late Anglo-Saxon England', ibid. pp. 226-57; K. Lowe, 'Lay Literacy in Anglo-Saxon England and the Development of the Chirograph', Anglo-Saxon Manuscripts and their Heritage, ed. P. Pulsiano and E. M. Treharne (Aldershot, 1998), pp. 161-204; C. Cubitt, “"As the Lawbook Teaches": Reeves, Lawbooks and Urban Life in the Old English Legend of the Seven Sleepers', EHR 124 (2009), 1021-49; and C. Insley 'Archives and Documentary Practice in the Anglo-Saxon World', Documentary Culture, ed. Brown, Costambeys, Innes and Kosto, pp. 336-62.

${ }^{3}$ Geary, 'Land, Language and Memory', p. 176. For a tabular representation of uses of vernacular languages in documentary practices throughout medieval Western Europe see T. Brunner, 'Le passage aux langues vernaculaires dans les actes de la pratique en Occident', Le Moyen Age 115.1 (2009), 29-72, at 37.

${ }^{4}$ See, for instance, Conceptualizing Multilingualism in England, c. 800-c. 1250, ed. E. M. Tyler, Studies in the Early Middle Ages 27 (Turnhout, 2011); E. Treharne, 'The Authority of English, 900-1150', in The Cambridge History of Early Medieval English Literature, ed. C. A. Lees, New Cambridge History of English Literature (Cambridge, 2012), pp. 554-78; H. Gittos, 'The Audience for Old English Texts: Ælfric, Rhetoric and "the Edification of the Simple", ASE 43 (2014), 231-66; R. Stephenson, The Politics of Language: Byrhtferth, Elfric and the Multilingual Identity of the
} 
the bilingualism of these written records has often been taken for granted, in spite of its profound implications for the study of documentary production, record keeping, legal transactions, disputes, public ceremonies and relations between the laity and the Church.

This article aims to address such issues by focusing on one of the most important archives of Anglo-Saxon charters, namely that of the cathedral of Worcester. In particular, it will concentrate on the charters produced there between the episcopates of Wærferth and Oswald, which represent an exceptional body of evidence for examining the relations between documentary practices and language choice during a period of rapid and significant transformations, marked by the rise of the West Saxon royal dynasty, the blossoming of a vernacular literary culture and the implementation of wide-reaching ecclesiastical reforms. Recent work on the archive of Christ Church, Canterbury has highlighted the important role that the vernacular had acquired there in the course of the ninth century, pointing in particular towards a preference for Old English over Latin when lay people, and perhaps, more specifically, lay women, were involved in the transactions recorded in surviving charters. ${ }^{5}$ This study of the Worcester archive provides an alternative perspective, from a different region, from a slightly later period, and with a body of material with several contrasting features to that from Canterbury. Much of the material from Worcester, for instance, comes in the form of episcopal leases, a type of document that is almost entirely absent at Canterbury, except for a single specimen issued by a Mercian archbishop - Plegmund - in the early tenth century. ${ }^{6}$ In addition, while the Christ Church archive is unique in preserving more than a hundred surviving single sheets, with a particularly high concentration in the ninth century, the Worcester charters have come down to us mostly thanks to the survival of two eleventh-century cartularies (and fragments of a third one). The earliest of the three, known as Liber Wigorniensis, is in fact the earliest extant English cartulary and the only surviving compilation of this kind from the Anglo-Saxon period, probably having been produced early on in the episcopate of Archbishop Wulfstan the Homilist, who held Worcester and York in plurality between 1002 and 1016. ${ }^{7}$ Most of the charters which will be discussed here have been preserved in Liber Wigorniensis and while it is because of the survival of such an early compilation that an investigation like this one is possible, one must also bear in mind that, as is often the case, the 'cartularization' process may have led to some modification of the texts of the charters, including some updating of the spelling of vernacular passages. However, the early date at which this particular cartulary was produced arguably makes the study of this archive easier and safer than investigation of many other Anglo-Saxon archives that have been

Benedictine Reform (Toronto, 2015); O. Timofeeva, 'Anglo-Latin Bilingualism before 1066: Prospects and Limitations', Interfaces between Language and Culture in Medieval England: a Festschrift for Matti Kilpiö, ed. A. Hall, O. Timofeeva, Á. Kiricsi and B. Fox (Leiden, 2010), pp. 1-36. It should be specified at the outset that we understand Latin as a written language that had to be learnt and was unlikely to have been a language of conversation in Anglo-Saxon England. On Latin as 'primarily a written language' in pre-Conquest England see M. Lapidge, 'How English is pre-Conquest Anglo-Latin?', Britannia Latina: Latin in the Culture of Great Britain from the Middle Ages to the Twentieth Century, ed. C. Burnett and N. Mann (London, 2005), pp. 1-13, at 3-4.

${ }^{5}$ N. Brooks, 'Latin and Old English in Ninth-century Canterbury', Spoken and Written Language: Relations between Latin and the Vernacular Languages in the Earlier Middle Ages, ed. M. Garrison, A. P. Orbán and M. Mostert with the assistance of S. Van Egmond, Utrecht Studies in Medieval Literacy 24 (Turnhout, 2013), 113-31; Charters of Christ Church, Canterbury, ed. N. Brooks and S. E. Kelly, AS Charters 17 and 18 (Oxford, 2013) [hereafter CantCC], $123-32$. ${ }^{6}$ S 1288. Charters are cited by their number in P. H. Sawyer, Anglo-Saxon Charters: an Annotated List and Bibliography (London, 1968), in its revised form available online as the 'Electronic Sawyer' (www.esawyer.org.uk), abbreviated $\mathrm{S}+$ number. Relevant editions are cited in any detailed discussion of particular texts.

${ }^{7}$ Liber Wigorniensis survives as London, British Library, Cotton Tiberius A. xiii, fols. 1-118. The other two eleventhcentury Worcester cartularies are known as Nero-Middleton and Hemming's cartulary. Of the former only some fragments survive as London, British Library, Cotton Nero E. i, pt 2, fols. 181-84 and London, British Library, Add. 46204, whereas Hemming is also contained in Cotton Tiberius A xiii, at fols. 119-200. See N. Ker, 'Hemming's Cartulary: a Description of the Two Worcester Cartularies in Cotton Tiberius A. xiii', Studies in Medieval History presented to F. M. Powicke, ed. R. W. Hunt, W. A. Pantin and R. W. Southern (Oxford, 1948), pp. 49-75; S. Baxter, 'Archbishop Wulfstan and the Administration of God's Property', Wulfstan, Archbishop of York: the Proceedings of the Second Alcuin Conference, ed. M. Townend, Studies in the Early Middle Ages 10 (Turnhout, 2004), 161-205; F. Tinti, Sustaining Belief: the Church of Worcester from c. 870 to c. 1100 (Farnham, 2010), pp. 85-150. 
preserved through much later charter compilations, within which interventions in the original texts may have accumulated over the course of several centuries.

\section{WORCESTER FROM W ÆRFERTH TO OSWALD}

To begin, some historical context is necessary. Relatively little is known about Worcester in the decades preceding the time of Bishop Wærferth; we cannot even be sure of either Wærferth's background or the exact dating limits of his episcopate, which began some time between 869 and $872 / 3$ and which ended with his death either in 907 or $915 .{ }^{8}$ What is clear is that Wærferth was an extraordinary bishop in extraordinary times. He is likely to have been far more politically influential than his predecessors, benefitting from the new political concord between the leaders of the West Saxons and the Mercians (that culminated in the creation of the 'kingdom of the Anglo-Saxons'). ${ }^{9}$ In particular, his close relationship with King Alfred appears to have brought the church of Worcester unusually close to the sphere of the West Saxon royal household. This new position is reflected in the personal literary activity of Wærferth who, according to Asser, translated Gregory the Great's Dialogi into Old English at the request of King Alfred, ${ }^{10}$ and who in turn received a copy of Alfred's own vernacular rendering of Gregory the Great's Regula pastoralis. ${ }^{11}$ It is thanks to these Alfredian connections and to a series of remarkable charters - to which we will turn shortly - that Wærferth's episcopate comes into view most clearly between the early 880 s and the early 900 s, allowing us to garner a sense of literary activity there despite a dearth of surviving manuscripts to which we can give a contemporary Worcester provenance. ${ }^{12}$

By the time of Wærferth's accession, the church of Worcester had already accumulated a vast landed estate thanks to the many grants that it had received from the rulers of the Hwicce and the kings of the Mercians in the course of the preceding two centuries, and it had also managed to acquire control of several religious houses in the territory of its diocese, together with their lands. Although the Viking attacks had had a strong impact on Mercia, Worcester was not seriously affected, thus possibly contributing to the maintenance of a relatively reasonable level of Latinity, as attested by Wærferth's career and accomplishments. During the latter's episcopate the cathedral

\footnotetext{
${ }^{8}$ For the episcopates of Wærferth's immediate predecessors see A. S. McKinley, 'Understanding the Earliest Bishops of Worcester c. 660-860', Leaders of the Anglo-Saxon Church: From Bede to Stigand, ed. A. R. Rumble (Woodbridge, 2012), pp. 77-95. John of Worcester says that Wærferth had been educated at Worcester and that his accession took place in 872; he also says that the bishop was ordained on 7 June, Whit Sunday, though 7 June was Whit Sunday in 873 : The Chronicle of John of Worcester, II: the Annals from 450 to 1066, ed. R. R. Darlington and P. McGurk with J. Bray (Oxford, 1995), pp. 300-1, n. 1. However, S 1278 - the earliest surviving document issued by Wærferth as bishop of Worcester - is indeed dated 872.

${ }^{9}$ S. Keynes, 'King Alfred and the Mercians', Kings, Currency and Alliances: History and Coinage of Southern England in the Ninth Century, ed. M. A. S. Blackburn and D. N. Dumville, Studies in Anglo-Saxon History 9 (Woodbridge, 1998), 1-45.

${ }^{10}$ Asser, Vita Alfredi regis, ch. 77, in Asser's Life of King Alfred, together with the Annals of Saint Neots, ed. W. H. Stevenson (Oxford, 1904), p. 62, with S. Keynes and M. Lapidge, Alfred the Great: Asser's 'Life of King Alfred' and Other Contemporary Sources (Harmondsworth, 1983), p. 92.

11 This copy still survives as Oxford, Bodleian Library, Hatton 20. For discussion see S. Keynes, 'The Power of the Written Word: Alfredian England, 871-899', Alfred the Great: Papers from the Eleventh-centenary Conferences, ed. T. Reuter (Aldershot, 2003), pp. 175-97.

${ }^{12}$ Numerous manuscripts survive that may have been at Worcester in the late ninth and early tenth centuries, though very few have a certain such provenance. The two strongest candidates are Oxford, Bodleian Library, Hatton 20 (the contemporary copy of the Old English Pastoral Care), whose Worcester provenance seems definite, and London, British Library, Royal 5. F. iii, a copy of Aldhelm's Prosa de uirginitate that may well have been produced at Worcester during this timeframe. As to other manuscripts possibly with a Worcester provenance contemporary with Wærferth, it should be noted that Old English is almost entirely absent amongst their contents. Beyond charters and extant manuscripts, furthermore, clues as to the range of literature at Worcester are disappointingly meagre: the Fontes Anglo-Saxonici project identified only two sources that Wærferth may have consulted while translating Gregory's Dialogi, namely the Dialogi themselves and the Bible. See R. Jayatilaka, 'The Sources of Wærferth, Dialogues (Cameron C.B.9.5)', 1997, Fontes Anglo-Saxonici: World Wide Web Register, http://fontes.english.ox.ac.uk/. For a summary of book production at Worcester during Wærferth's episcopate see R. Gameson, 'Book Production and Decoration at Worcester in the Tenth and Eleventh Centuries', St Oswald of Worcester: Life and Influence, ed. N. Brooks and C. Cubitt (London, 1996), pp. 194-243, at 194-6.
} 
community also seems to have grown, since one of the leases issued by the bishop (which happens to be the only one to survive on single sheet) is attested by as many as thirty members of the community, in contrast with the more limited number of attestations which can be found in the documents issued by his predecessor, Ealhhun. ${ }^{13}$

For the period between Wærferth and Oswald we are noticeably less informed about developments at Worcester. The former's episcopate was followed by two considerably shorter ones; for the first - that of Æthelhhun (915-915x922) - we do not have any surviving episcopal documents; whereas for the second - Wilfrith's $(915 \times 922-928 \times 929)$ - only one document has been preserved. ${ }^{14}$ Wilfrith was succeeded by a much better known figure - Cenwald, who became bishop of Worcester in 928 or 929 and whose episcopate lasted some thirty years. ${ }^{15}$ If Cenwald can be described as a better known historical figure than his immediate predecessors, it is not, however, so much for his activities as bishop of Worcester (in his case too, one only episcopal document has survived), ${ }^{16}$ but rather for his involvement in a number of national and international affairs, including the leadership of a diplomatic mission to Germany that was entrusted to him by King Æthelstan in 929. Yet most relevant for present purposes is his likely authorship of the so-called 'alliterative charters', a group of royal diplomas ranging in date from 940 to 956, which display a number of distinctive features and which, as will be shown further below, must be borne in mind when assessing the significance of the development of documentary production at Worcester in the tenth century. ${ }^{17}$

Cenwald was succeeded by Dunstan, the later archbishop of Canterbury and famed Benedictine reformer, whose Worcester episcopacy was, however, very brief. Lasting just a year or so, in 961 the Worcester community welcomed a new bishop, Oswald, who went on to hold the see until his death in 992. ${ }^{18}$ Oswald's pontificate is probably the best-known period in the entire AngloSaxon history of Worcester cathedral; this is in large part due to the remarkable series of episcopal leases which have survived from Oswald's time and which provide much of the most significant evidence for the present study. During his episcopate, Worcester was one of the main English cathedral churches whose communities were reformed in the second half of the tenth century. Changes, however, seem to have been introduced more gradually at this cathedral church than, for example, at Winchester, since the attestations of the community members in the episcopal leases indicate that the introduction of a new way of life did not involve any sudden purge of the secular clergy. ${ }^{19}$ Indeed, it is difficult to say what exactly the reform entailed at Worcester. In contrast with other reform centres such as the Old and the New Minsters at Winchester, or Glastonbury,

Abingdon and Ramsey, from Worcester we do not have any eye-witness accounts of the development of reform there, nor was any of the major surviving propagandistic texts emanating from the reform composed at Worcester. Rather, our main narrative source is Byrhtferth's Vita Oswaldi, which in any case is much more focused on Ramsey - the author's monastery - than on Worcester. Furthermore, only a small number of manuscripts of the late tenth century can be associated with Worcester. That said, it is probably thanks to Oswald's contacts with the Continent, especially the monastery at Fleury, where he lived between 955 and 958, that the cathedral church

\footnotetext{
${ }^{13}$ S 1281 (Anglo-Saxon Charters, ed. A. J. Robertson, 2nd ed. (Cambridge, 1956) [hereafter ASChart], no. 18); Tinti, Sustaining Belief, pp. 9-14.

${ }^{14} \mathrm{~S} 1289$.

${ }^{15}$ Although his name is usually normalized as 'Cenwald', it should be noted that it appears in a tenth-century addition to the Worcester manuscript of the Old English Pastoral Care (Hatton 20, 98v) as 'Koenwald'; see Tinti, Sustaining Belief, pp. 16-17. On Wærferth's immediate successors see ibid. pp. 14-15.

${ }^{16} \mathrm{~S} 1290$.

${ }^{17}$ See below, text corresponding to $\mathrm{nn} .102-106$.

${ }^{18}$ In 971 Oswald was also elected archbishop of York and held the two sees in plurality until his death. See N. P. Brooks, 'Oswald [St Oswald] (d. 992)', Oxford Dictionary of National Biography, Oxford University Press, 2004 [http://www.oxforddnb.com/view/article/20917, accessed 7 Sept 2016].

${ }^{19}$ See Tinti, Sustaining Belief, pp. 25-38 and bibliography cited there.
} 
acquired at least two books. ${ }^{20}$ Further suggestion of an expanding library during Oswald's time is found with Hemming, writing a century later, who noted that Oswald had granted a lease of land in favour of a cleric named Goding on account of the many books that he had written for the monastic community. ${ }^{21}$ What remains in any case relevant for present purposes is that the few surviving manuscripts which can be associated with Worcester at this time do not display any pronounced interest in the vernacular. ${ }^{22}$ Several important vernacular manuscripts do survive from the eleventh century, but the main evidence for literacy, the uses of the written word and the relative status of Latin and Old English at Worcester throughout the period under investigation here comes from charters.

Before turning to the documents themselves, a final point to stress is that in our investigation we have focused primarily on those charters which are most likely to have been composed at Worcester. While such an attribution is fairly safe when considering the leases issued by the bishops who held the see throughout the period, or the records of disputes which took place in the territory of the diocese and in which the church of Worcester was involved as one of the litigants, royal diplomas pose a more complex problem. The period and the region under investigation witnessed important changes on this front, both because of the process that took the main centre of power in England from Mercia to Wessex, and because of the concurrent emergence of a central West Saxon agency for the production of royal diplomas. ${ }^{23}$ The origins and the actual extent of the work carried out by such an agency have been hotly debated, and while we do not aim at contributing to such a debate, we have tried to establish which charters among those preserved within the Worcester archive can be considered in-house productions. As will emerge further below, such a task can be rather challenging when dealing with the documents issued in the name of the Mercian leaders in Wærferth's time, whereas the royal diplomas issued by the end of our period can be safely assumed to be the fruit of centralized production. Having said that, it should be stressed that our investigation of documentary culture at Worcester does not stop with the identification of what was written there, as the members of the community would have been recipients as well as producers of charters, and what was received clearly informed and influenced their documentary output.

\section{THE CHARTERS OF WÆRFERTH'S EPISCOPATE}

We begin our investigation proper with the charters from Wærferth's episcopate. These records follow on from several decades of documentary innovation in Anglo-Saxon England, with the

\footnotetext{
${ }^{20}$ Gameson, 'Book production', pp. 196-8. Despite the relative dearth of manuscripts with definite tenth-century Worcester provenances, Gameson argued that the reading habits of the community are unlikely to have changed significantly during the second half of the tenth century.

${ }^{21}$ The lease itself, S 1369 (ASChart 61), has survived in Liber Wigorniensis. See Tinti, Sustaining Belief, p. 34.

${ }^{22}$ See M. Gretsch, 'Literacy and the Uses of the Vernacular', The Cambridge Companion to Old English Literature, ed. M. Godden and M. Lapidge, 2nd ed. (Cambridge, 2013), pp. 273-94. For a list of books that can be associated with Worcester in the period between the late ninth and the late eleventh century see Gameson, 'Book Production', pp. 23642. This list can be augmented through collation with H. Gneuss and M. Lapidge, Anglo-Saxon Manuscripts: a Bibliographical Handlist of Manuscripts and Manuscript Fragments Written or Owned in England up to 1100 (Toronto, 2014), though in terms of vernacular contents only one manuscript (Oxford, Corpus Christi College 197, no. 672 in Gneuss and Lapidge's Handlist, containing the earliest bilingual copy of the Rule of St Benedict) can be added to those already listed by Gameson for the period from Wærferth to Oswald. It must be stressed, however, that Gneuss and Lapidge's attribution of the origins of this manuscript to Worcester is only tentative (i.e., it is followed by a question mark) and it proceeds from N. R. Ker's observation in his Catalogue of Manuscripts Containing Anglo-Saxon (Oxford, 1957), p. xxvi of 'a certain resemblance' with the script of S 1347 (London, British Library, Add. Charter 19794), one of the two surviving original single sheets from Oswald's time. Subsequent commentators have remained somewhat sceptical about this Worcester connection; see for instance D. N. Dumville, English Caroline Script and Monastic History: Studies in Benedictinism, A.D. 950-1030, Studies in Anglo-Saxon History 6 (Woodbridge, 1993), 19-30 and 56, and R. Gameson, 'The Material Fabric of Early British Books', The Cambridge History of the Book in Britain, I, c. 400-1100, ed. R. Gameson (Cambridge, 2012), pp. 13-93, at 40.

${ }^{23}$ S. Keynes, 'The West Saxon Charters of King Æthelwulf and his Sons', EHR 109 (1994), 1109-49; Keynes, 'King Alfred and the Mercians'; B. Snook, The Anglo-Saxon Chancery: the History, Language and Production of AngloSaxon Charters from Alfred to Edgar, Anglo-Saxon Studies 28 (Woodbridge, 2015), ch. 1. See also below, text corresponding to $\mathrm{n} .71$.
} 
earlier ninth century witnessing, for instance, the introduction of sequential boundary clauses and the earliest appearance of Old English wills. ${ }^{24}$ Specifically at Worcester, examples of predominantly vernacular charters survive from as early as the $820 \mathrm{~s}$, though there is relatively little such material from the middle decades of the century. The Old English documentary material from Wærferth's time could, therefore, be interpreted as reflective of a somewhat reinvigorated vernacular documentary culture at the end of the ninth century. In total there are eighteen charters surviving in the Worcester archive from the time of Wærferth that are likely to be authentic, only one of which is extant in its original form. Categorization of these documents is not always straightforward, given the fact that some represent unusual or perhaps even unique agreements and circumstances. The miscellaneous character of several of these texts, moreover, may be indicative of the relative lack of uniformity and standardization in how charters were produced at this time. The eighteen documents can, nevertheless, be divided for convenience into three groups: episcopal leases; memoranda of disputes; and charters issued in the names of the West Saxon and Mercian rulers. ${ }^{25}$ Each group has its own distinct contribution to make to our understanding of documentary practice at Worcester, not least in regards to the uses of written Latin and Old English.

\section{Episcopal leases}

Let us start with the most cohesive group of documents, namely the episcopal leases. It should first be stated that neither leasing nor the written lease was an innovation of Wærferth's episcopate. Such documents survive in the Worcester archive from the very early eighth century onwards, albeit in small numbers ${ }^{26}$ while comparable specimens from the Peterborough archive and (probably) from Hereford demonstrate that the production of written leases had earlier taken place elsewhere within Mercia and its hinterlands in the later eighth and ninth centuries. ${ }^{27}$ One of the examples from Peterborough, dating to 852, is particularly interesting, since it was written predominantly in the vernacular. ${ }^{28}$ For an ecclesiastical community, the motivations for the leasing of land were

\footnotetext{
${ }^{24}$ For vernacular wills see K. A. Lowe, 'The Nature and Effect of the Anglo-Saxon Vernacular Will', The Journal of Legal History 19.1 (1998), 23-61; L. Tollerton, Wills and Will-Making in Anglo-Saxon England (Woodbridge, 2011). For sequential boundary clauses, or, in Kathryn Lowe's words, descriptions of bounds proceeding 'logically from marker to marker in the course of [their] circular route', see K. A. Lowe, 'The Development of the Anglo-Saxon Boundary Clause', Nomina: Journal of the Society for Name Studies in Britain and Ireland 21 (1998), 63-100, at 69. For a more general overview of documentary developments in the first half of the ninth century see now R. Gallagher, 'The Vernacular in Anglo-Saxon Charters: Expansion and Innovation in Ninth-Century England', Historical Research 91 (2018), 205-35.

${ }^{25}$ In addition to these eighteen documents we should also note the survival of an Old English charter that may well represent a translation of an earlier Latin charter: S 98 (ASChart 1), an eighth-century record of a remission of shipping tolls donated by Æthelbald, king of Mercia to Milred, bishop of Worcester. For discussion of this document see S. Kelly, 'Trading Privileges from Eighth-Century England', EME 1 (1992), 3-28, at 5 and 24. Robertson, ASChart, p. 259 , following the advice of H. M. Chadwick, suggested that the translation of S 98 may have taken place at the time of Wærferth, since 'the non-West Saxon forms are all late Mercian'; we should bear in mind here the new commercial interests in London that were acquired by Wærferth, as attested by S 346 and 1628. Robertson, ASChart, p. 260 also notes that a second extant document, S 126 (ASChart 2), recording a grant of land by Offa, king of Mercia, to the church at Worcester, may also have been translated into the vernacular during Wærferth's time; the Old English of this document, however, contains no features that would suggest a date for translation earlier than the eleventh century. Our thanks to Richard Dance for his advice regarding this matter.

${ }^{26}$ Worcester episcopal leases from before Wærferth's episcopate include S 1254, 1255, 1262, 1272 and 1273 . More anomalous or spurious examples are S 1252, 1260 and 1261. Throughout this article, in instances where we cite several charters at once, they are listed in chronological order; further below, the chronological ordering of Oswald's leases follows S. Keynes, An Atlas of Attestations in Anglo-Saxon Charters, c. 670-1066, ASNC Guides, Texts and Studies 5 (Cambridge, 2002), Table LXXVI.

${ }^{27}$ The specimens from Peterborough, issued in the name of the abbot, are S 1412 and 1440; the specimen probably from Hereford, issued on behalf of Bishop Cuthwulf, is S 1270. Alongside these, one might wish to consider S 1791, recording an unusual arrangement whereby Ceolberht, bishop of London, issued a grant of land sometime between 827 and 840 with the stipulation that the land be returned if the beneficiary's line of inheritance died out. Also of particular interest is the small number of episcopal leases surviving in the archive of the Old Minster, Winchester from the second half of the ninth century onwards; for further comment on these see below, n. 151 .
}

${ }^{28}$ S 1440 (Charters of Peterborough, ed. S. E. Kelly, AS Charters 14 (Oxford, 2009) [hereafter Pet], no. 9. 
numerous and varied. Often issued in return for rent or a payment in kind, leasing offered a quick and easy way to exploit tenurial possessions. It also represented a potential strategy for developing and strengthening social networks ${ }^{29}$ in addition, it could act as an aid in resolving disputes over land ownership. Leasing was, in other words, a flexible and appealing option for many situations, offering the ability to hand over land to a beneficiary for a single generation or more and allowing ecclesiastical landowners to manipulate the administration of the local landscape in response to changing circumstances.

There are seven surviving episcopal leases from Wærferth's Worcester that are likely to be authentic. One of these charters survives in its original form (S 1281). Of the other six, two are preserved only thanks to Liber Wigorniensis (S 1279 and 1415); a further two appear in both Liber Wigorniensis and the Nero-Middleton cartulary (S 1278 and 1280); the remaining two exist exclusively as early modern transcriptions of now lost originals (S 1283 and 1416). As Table 1 demonstrates, the oldest survives from very early on indeed; dating to 872, it may represent one of Wærferth's first actions as bishop. This charter tells us that Wærferth, with the permission of his community, leased two hides of land at Nuthurst, Warwickshire, to a minister called Eanwulf in return for twenty mancuses of gold and, strikingly, it states that the bishop agreed to do so due to the suffering and immense tribute imposed by Viking invaders ('pagani'), who were at this time occupying London. ${ }^{30}$ The remaining six examples date to considerably later. In 889 and 892 , Wærferth, with the approval of the community, issued leases of land to himself, while from between 899 and 904 we have four further leases, bestowed respectively to a priest, ${ }^{31}$ to a kinswoman, ${ }^{32}$ to a reeve, ${ }^{33}$ and to the Mercian leaders, Ealdorman Ethelred and Ethelflæd. ${ }^{34}$ None of these later six examples offer substantial descriptions of the motivations behind their creation, ${ }^{35}$ though in all cases it is explicitly stated that the lease was issued by Bishop Wærferth together with the community at Worcester, with none mentioning the permission of any higher or secular authorities. $^{36}$

Table 1: Episcopal leases in the name of Bishop Wærferth

\footnotetext{
${ }^{29}$ See the brief discussion by D. A. Bullough, Friends, Neighbours and Fellow-drinkers: Aspects of Community and Conflict in the Early Medieval West, H. M. Chadwick Memorial Lectures 1 (Cambridge, 1990), 18-24.

${ }^{30}$ S 1278 (W. de G. Birch, Cartularium Saxonicum, 3 vols. (London, 1883-94) [hereafter BCS], nos. 533-4).

${ }^{31} \mathrm{~S} 1279$ (BCS 580).

${ }^{32}$ S 1283 (ASChart 16). The kinswoman, named Cyneswith, was leased three hides of an estate of five hides that had previously been leased to Wærferth in 889 (see S 1415 (BCS 559)). The other two hides issued in S 1415 were, as S 1283 tells us, to be held for the remainder of the lease by Prestbury, which appears to have been one of Worcester's episcopal manors: see P. Sims-Williams, Religion and Literature in Western England, 600-800, CSASE 3 (Cambridge, 1990), 139, n. 110, and 157-8.

${ }^{33}$ S 1281 (ASChart 18).

${ }^{34} \mathrm{~S} 1280$ (ASChart 19).

${ }^{35}$ Though several of these episcopal leases make reference to the friendship between the benefactor and beneficiary (sodalitas and amicitia in S 1279; freond in S 1280; 'loyal efficiency and humble obedience' ('holdum mægene 7 eadmodre hernesse') in S 1281).

${ }^{36}$ In this regard the leases of Wærferth sit in contrast to those of Oswald. See F. Tinti, 'Writing Latin and Old English in Tenth-Century England: Patterns, Formulae and Language Choice in the Leases of Oswald of Worcester', in Writing, Kingship and Power in Anglo-Saxon England, ed. R. Naismith and D. A. Woodman (Cambridge, 2018), pp. 303-27.
} 


\begin{tabular}{cccc}
\hline Sawyer & Date & $\begin{array}{c}\text { Dominant } \\
\text { language }\end{array}$ & Beneficiaries \\
\hline 1278 & 872 & Latin & minister regis Eanwulf \\
1415 & 889 & Latin & Bishop Wærferth \\
1416 & 892 & Latin & presbyter Werwulf \\
1279 & 899 & Latin & min mag Cyneswith; \\
1283 & $899 \times$ & Old English & \\
1280 & 904 & Latin/Old English & Ealdorman Ethelred and Æthelflæd \\
1281 & 904 & Old English & min gerefa Wulfsige \\
\hline \hline
\end{tabular}

As a group, these seven documents are a remarkable mixture of Latin and Old English prose. Four are predominantly in Latin, two are predominantly in the vernacular, while a seventh is thoroughly bilingual. Aside from this seventh specimen, to which we will return, there is relatively little code-switching within any one of these texts. Two examples are, however, noteworthy. First, in a lease issued in favour of a priest named Werwulf (feasibly the same Werwulf that Asser names as a priest within King Alfred's household) ${ }^{37}$ we find specific vernacular terminology relating to church dues - cirsceat and sawlsceat - couched in prose that is otherwise entirely in Latin. ${ }^{38}$ While church scot is referred to as census ecclesiae in at least one other charter, there are no known Latin analogues from Anglo-Saxon England for soul scot, which may explain the use of vernacular terms here, employed in order to differentiate precisely between the two types of due. ${ }^{39}$ In the lease issued for Bishop Wærferth himself in 892, meanwhile, the text is entirely in Latin up to the end of the passage introducing the witness-list, yet Wærferth's attestation, which tops the witness-list, is in Old English; this is particularly interesting, given the ritualistic overtones of its reference to the cross of Christ. ${ }^{40}$ The remainder of the attestations simply comprise names and, in some cases, Latin titles, but this is then followed by a final (now fragmentary) vernacular clause that appears to

\footnotetext{
37 Tinti, Sustaining Belief, p. 19, n. 45 notes that Werwulf does not seem to have belonged to the cathedral community, since his name does not appear in any of the surviving witness-lists. For the identification of the priest Werwulf mentioned by Asser with the beneficiary of S 1279 see Keynes and Lapidge, Alfred the Great, pp. 259 and 293. ${ }^{38}$ S 1279 (BCS 580).

${ }^{39}$ For the use of 'census ecclesiae' see, for example, S 1415 (BCS 559). For discussion of both church scot and soul scot see F. Tinti, 'The "Costs" of Pastoral Care: Church Dues in Late Anglo-Saxon England', Pastoral Care in Late Anglo-Saxon England, ed. F. Tinti, Anglo-Saxon Studies 6 (Woodbridge, 2005), 27-51.

${ }^{40}$ S 1416 (BCS 570). Wærferth's attestation reads as follows: 'Ic perferd biscop mid minre agenre honda .7 Cristes rode tacne Dis gesetenesse gefæstnigu' ('I Bishop Wærferth confirm this agreement with my own hand and the sign of the cross of Chris'). Note that unless otherwise stated all excerpts of charter text quoted in our discussion are printed as they are found in the cited edition.
} 
summarize the agreement and confirm that the Worcester community had attested it. ${ }^{41}$ Since this lease only survives as a seventeenth-century transcription, we are unable to draw on palaeographic evidence to help explain the switch into Old English. However, given other evidence from within Wærferth's charters, as we will see shortly, this may well indicate a second stage of writing.

How can we explain the linguistic differences amongst these seven leases? First, it should be stressed that despite the fact that only one of these documents survives in its original form, there is little reason to doubt the languages in which Wærferth's leases are preserved - especially when we remember that both Latin and Old English are found amongst those that were included in Liber Wigorniensis. With that in mind, we may note that the four leases definitely issued before 900 are predominantly Latin documents, while those that may or certainly date to the early 900 s are partially or entirely in the vernacular. Thus, one possibility is that this represents a simple chronological development, with the introduction of Old English leases occurring at the turn of the tenth century - several years, it should be noted, after Wærferth had completed his translation of Gregory the Great's Dialogi, which he had done by 893 at the very latest. ${ }^{42}$ We are dealing, however, with a very small number of documents and other variables cannot be discounted. It is notable, for example, that three of the four earlier leases were issued in favour of members of the clergy, while the recipients of all three of the later leases were lay individuals. Another possible explanation, therefore, may be that language choice reflected the varying literacies of the beneficiaries - the introduction of Old English leases may have been a response to the rising number of (lay) individuals who could read in the vernacular - or, alternatively (but not mutually exclusively), the use of the vernacular for lay beneficiaries perhaps betrays an association that draftsmen wished to advance between ecclesiastical life and Latinity. Such an interpretation could, of course, be sustained alongside a chronological interpretation. Above all, however, in each case the specific context to the production of the charter needs to be borne in mind. This is easier said than done for most of these documents, given the lack of further information that we have about most of the beneficiaries and land with which these charters are concerned, but it can at least be used to explain the linguistic dynamics of our most bilingual lease, S 1280, which was issued in favour of Ealdorman Æthelred and Æthelflæd in $904 .{ }^{43}$ Within this document, Wærferth and his community leased not only a considerable amount of land at Barbourne in North Claines, Worcestershire, but also a sizeable riverside plot within the recently fortified burh of Worcester. ${ }^{44}$ Given that the charter specifies that this lease should last the duration of the lives of Æthelred, Æthelflæd and their daughter, Ælfwyn, this agreement was, therefore, a clear declaration of support for the current Mercian ruling dynasty, at a time when the future of the political status quo was perhaps somewhat uncertain, particularly in light of the challenge to the throne that Æthelflæd's brother, Edward, had recently faced. ${ }^{45}$ This document was issued in the same year as the only surviving single-sheet charter from Wærferth's episcopate, a three-generation lease for a reeve named Wulfsige. ${ }^{46}$ While Wulfsige's lease is entirely in Old English, in contrast, this deeply political contract between Worcester and the Mercian rulers switches multiple times between Latin

\footnotetext{
${ }^{41}$ The vernacular summary reads as follows: 'Ec se heorod mid Cristes rode tacne .... ine gefestnode ...... erfe peardum pere á elc $\partial$ ara monna únbesecen. on $\partial \mathrm{em}$. . . . undum pere de . . . me ge preotan to $\partial \mathrm{em}$ dege $\partial \mathrm{e}$ me unnende ge selde' ('And the household with the sign of the cross of Christ ... confirmed ... to the heirs were uncontested to each of the men in the ... were ... on the day that ... gave ... granting ... to me ... '). Our thanks to Philip Shaw and Kate Wiles for advice concerning this suggested translation.

42 J. M. Bately, 'Old English Prose Before and During the Reign of Alfred', ASE 17 (1988), 93-138, at 103.

${ }^{43} \mathrm{~S} 1280$ (ASChart 19).

${ }^{44}$ The land at Worcester is described as a haga and it is likely to have served commercial purposes. For discussion see N. Baker and R. Holt, 'The City of Worcester in the Tenth Century', St Oswald of Worcester, ed. Brooks and Cubitt, pp. $129-46$, at 134.

${ }^{45}$ Namely the rebellion of Edward's cousin Æthelwold, which took place between 899 and 902 . For a recent discussion of this development see R. Lavelle, 'The Politics of Rebellion: the AEtheling Æthelwold and West Saxon Royal Succession, 899-902', Challenging the Boundaries of Medieval History: the Legacy of Timothy Reuter, ed. P. Skinner, Studies in the Early Middle Ages 22 (Turnhout, 2009), 51-80.

${ }^{46}$ S 1281 (ASChart 18).
} 
and the vernacular: it opens with a Latin proem; switches into Old English for the dispositive section; switches back into Latin for the sanction and blessing; returns to Old English for the introduction to the witness-list and the attestations of Æthelred and Æthelflæd; and again switches to Latin for six further attestations (including that of Wærferth). ${ }^{47}$ These are followed by more names and titles, some of which are in Latin and others in Old English, before ending with a final phrase in the vernacular summarizing the agreement. ${ }^{48}$ The changes of language within the witnesslist are perhaps to be explained by the manner in which the attestations were recorded, possibly in a second stage of writing and conceivably reflecting the linguistic identity of the Latinate church as opposed to their lay beneficiaries. The most striking aspect, however, is the inclusion of a Latin proem, blessing and sanction, without which this would be an almost entirely vernacular text. These three sections provide no practical details; their presence is largely performative and no doubt a reflection of the heightened symbolic importance of this lease. ${ }^{49}$

Across this group of seven leases, it should be noted that there is little repetition of phrasing. This, alongside the relative lack of code-switching, sets these documents apart from most Worcester leases from later in the tenth century. The apparent absence of a distinct set of stock phrases may simply be reflective of the small number of leases surviving from Wærferth's episcopate, but it may also suggest that Worcester draftsmen had yet to develop formulae specifically for the production of such documents. Instead, perhaps the most striking feature of any one of these charters is the use of an Old English invocation, different examples of which are found in vernacular leases, as well as in dispute memoranda and other forms of documentation produced at Worcester at this time. ${ }^{50}$ Despite the production of predominantly Old English charters in Anglo-Saxon England since the beginning of the ninth century, there are no earlier examples of vernacular invocations from elsewhere. They appear, therefore, to be an innovation of Wærferth's Worcester.

A final point relates to what is possibly the earliest episcopal lease written mainly in the vernacular. Issued some time between 899 and 904, this document was granted in favour of a kinswoman of Wærferth named Cyneswith. ${ }^{51}$ Its prose is noticeably more descriptive than contemporary Latin charters; thus we find the following passage, which offers a unique glimpse at documentary practice in action: 'all higen eodan to minum bure on Weogornaceastre 7 me saldan heora hondsetene ðisse geraednesse' ('all the members of the community went to my bur in Worcester and gave me their signature to this agreement'). ${ }^{52}$ This lease unambiguously tells us,

\footnotetext{
${ }^{47}$ It should be noted that similar (though not identical) proems to that found in $\mathrm{S} 1280$ are contained in a series of royal diplomas of the 940s and 950s (S 465, 474, 481, 640 and 643); a variant of this proem also features in a spurious Evesham charter of the year 710 (S 81). The joint blessing and sanction, on the other hand, is unique, although it does share the form of the verb 'redarguantur' with an invocation of a royal diploma of 943 (S 489). The similarities with diplomatic of the 940s should not immediately condemn the Latin portions of S 1280 as later additions. None of these royal diplomas with similar formulations are from the Worcester archive, while we should not discount the impact that Worcester diplomatic may have had on tenth-century royal diplomatic.

${ }^{48}$ We cannot discard the possibility that this final vernacular phrase, which in both cartulary copies is found at the very end of the charter, was an endorsement on the original single sheet. The text as edited in ASChart 19 reads as follows: 'Æperedes gerædnesse 7 Æpelflæde wið Werfrið b[isceope] 7 wip pone hired on WegernaceaSTER'. Note that this phrase (with orthographic variation) up to and including the abbreviation for the word bisceop was also used in the Nero-Middleton copy as an initial rubric.

${ }^{49}$ For the concept of early medieval charters as 'performative' see G. Koziol, The Politics of Memory and Identity in Carolingian Royal Diplomas: the West Frankish Kingdom (840-987), Utrecht Studies in Medieval Literacy 19 (Turnhout, 2012), 42-62. Koziol's work has inspired several recent publications on Anglo-Saxon charters: see, for example, C. Insley, “'Ottonians with Pipe Rolls”? Political Culture and Performance in the Kingdom of the English, $c$. 900-c.1050', History 102 (2017), 772-86; L. Roach, 'A Tale of Two Charters: Diploma Production and Political Performance in Æthelredian England', in Writing, Kingship and Power in Anglo-Saxon England, ed. Naismith and Woodman, pp. 234-56.

${ }^{50} \mathrm{~S} 223,1441,1283,1446$ and 1281.

${ }^{51} \mathrm{~S} 1283$ (ASChart 16). This charter is part of a group of twenty-four now lost single sheets that belonged c. 1700 to Lord Somers. They survive only as transcriptions that were printed in the eighteenth century. See S. Keynes, 'AngloSaxon Charters: Lost and Found', Myth, Rulership, Church and Charters: Essays in Honour of Nicholas Brooks, ed. J. Barrow and A. Wareham (Aldershot, 2008), pp. 45-66, at 58-9.

52 Text and translation adapted from ASChart 16.
} 
therefore, that the agreement was attested in a second stage of proceedings, perhaps exclusively by members of the Worcester community, ${ }^{53}$ within the relatively intimate space of Wærferth's bur. What exactly the bur constituted is not clear - this word is elsewhere found to denote a variety of indoor spaces, primarily with a degree of privacy, including bedrooms and dining rooms - though most strikingly, it can also be found in the contemporary 'Fonthill Letter', in which we are told that King Alfred washed his hands and dispensed advice concerning a dispute while in his bur. ${ }^{54}$ It is similarly unclear what would have constituted the giving of a signature - if, for example, the main body of the witness-list had been written ahead of this confirmation act - and what ritual may have taken place during this event; we should not be surprised if procedures varied from occasion to occasion. It should be noted that possible parallels can be found with several single-sheet charters in the Christ Church, Canterbury archive whose witness-lists were evidently the work of a second scribe ${ }^{55}$ In contrast, however, the only one of Wærferth's leases to survive in its single-sheet form does not conclusively attest to multiple stages of writing, although the crosses beside the names of each of the witnesses do vary significantly. ${ }^{56}$ In this case, it is possible that the 'signing' of the agreement may have involved the addition of autographed crosses, a practice ultimately derived from Italian diplomatic that allowed the participation of witnesses who were otherwise illiterate. ${ }^{57}$ In light of this evidence, the aforementioned switch from Latin into Old English for the witness-list of the lease of 892 (S 1416) seems particularly suggestive of two-stage production.

\section{Dispute memoranda}

We move on now to our second body of charters from Wærferth's episcopate, the miscellaneous group of documents that are best described as dispute memoranda. These are, in other words, texts that present themselves as recording the outcome of a disagreement regarding the ownership of land. Here it should be noted that other Worcester charters from Wærferth's time may well relate to such disputes, but either they do not explicitly refer to discord or the references are embedded in documents that are best described first and foremost in others ways; we shall meet one example of the latter shortly. As to those charters that are focussed primarily and explicitly on dispute resolution, such documents had been produced in the eighth and earlier ninth centuries at Worcester and at other ecclesiastical centres, including Selsey, Shaftesbury and Christ Church, Canterbury. ${ }^{58}$ The vast majority of these earlier examples speak in the third person and in Latin, projecting an impression of impartiality and of a dispute that had been definitively resolved. More often than not they also contain a witness-list recording the most senior and prominent individuals who were present at the meeting at which the dispute was debated. In the earlier Anglo-Saxon period, arguments over landownership - particularly if they involved an ecclesiastical party - were brought to church councils for resolution and the records of such disputes were normally produced by the victorious party after the event had passed. ${ }^{59}$ Thus, many of these documents are deeply partisan. In

\footnotetext{
${ }^{53}$ Of the twenty-two individuals included within the witness-list, twenty attest at least one other Worcester charter. The two other individuals (named Eamberht and Wigfrith) are otherwise unknown.

${ }^{54}$ S 1445 (CantCC 104). Our thanks to Jinty Nelson for bringing this verbal parallel to our attention. For a recent discussion of bur and, in particular, its relation to burpen see J. Lloyd, 'The Priests of the King's Reliquary in AngloSaxon England', JEH 67 (2016), 265-87, at 275-6.

${ }^{55}$ For example, S 8, 155, 1264, 1268, 293, 1196, 1200 and 1508.

${ }^{56}$ For further discussion of this single sheet see the Appendix; for images see Figures 1a and $1 \mathrm{~b}$.

${ }^{57}$ The case for such a practice existing in Anglo-Saxon England has been put forward on several earlier occasions, though the evidence has not been strong enough to prove decisive. For a recent discussion of this matter see $\mathrm{S}$. Keynes, 'Church Councils, Royal Assemblies, and Anglo-Saxon Royal Diplomas', Kingship, Legislation and Power in AngloSaxon England, ed. G. R. Owen-Crocker and B. W. Schneider, Publications of the Manchester Centre for Anglo-Saxon Studies 13 (Woodbridge, 2013), 17-182, at 66, 70, 73, 91, 113-16 and 166.

${ }^{58}$ For example, from Shaftesbury: S 1256; from Selsey: S 158 and 1435; from Christ Church, Canterbury: S 1258, 1434, 1436, 1438 and 1439; from Worcester: S 1429, 1430, 137, 1431 and 1433.

${ }^{59}$ P. Wormald, 'Charters, Law and the Settlement of Disputes in Anglo-Saxon England', The Settlement of Disputes in Early Medieval Europe, ed. W. Davies and P. Fouracre (Cambridge, 1986), pp. 149-68, repr. in and cited from his Legal Culture in the Early Medieval West: Law as Text, Image and Experience (London, 1999), pp. 289-311, at 293.
} 
the second half of the ninth century, however, church councils disappear from the historical record and it seems that the meetings of the witan became the venue for many of these disputes instead. There are three such charters surviving in the Worcester archive from Wærferth's time, all three dating to shortly before or after the year 900, a time when Wærferth and the Worcester community evidently were attempting to consolidate and expand the power of their church through the resolution of long-standing land disputes. These three documents can all be found in Liber Wigorniensis - two exclusively so - and all three are markedly different from each other in both form and language.

The earliest example dates to 896 and relates to a quarrel over land at Woodchester in Gloucestershire which had been on-going for several decades. ${ }^{60}$ This document is entirely in Old English and reports the unfolding events as if it were a third party observer. It tells us that Wærferth took the dispute to a meeting at Gloucester that Ealdorman Æthelred had organized and which was attended by several bishops, ealdormen and other members of the nobility. At the meeting, Wærferth claimed that the land had originally been given to the church at Worcester by the Mercian King Æthelbald (716-757), but it had since been stolen and was currently in the possession of a priest called Æthelwald, who was also present to hear Wærferth's account. Æthelwald, we are told, did not dispute Wærferth's words and thus he ordered his own geneat, a man named Ecglaf, to ride with Wulfhun, one of Wærferth's priests, along the perimeter of the disputed territory. As Ecglaf led the Worcester priest, one of the two individuals - most likely, Wulfhun - read out the bounds as they were written in King Æthelbald's diploma. ${ }^{61}$ With this having been done, it was agreed that Ethelwald would lease the land from Worcester for the duration of his and his son's lives; leasing, therefore, was employed as a means of diplomacy. This record offers extremely rare evidence for the function that earlier charters - and, more specifically, their bounds - could have played in a dispute. ${ }^{62}$ It is particularly noteworthy that the riding of the bounds does not appear to have been a ceremonial final act in the resolution of the dispute: the negotiations continued after this was done and it seems, moreover, to have had a very practical purpose, ensuring that both parties were in agreement about exactly what lands were under discussion. As to the memorandum itself, it is not immediately clear why it was composed entirely in the vernacular, although it should be stressed that this is not the earliest Worcester record of a dispute to have been written predominantly in Old English; two specimens survive that purport to have been composed in the $820 \mathrm{~s} .{ }^{63} \mathrm{We}$ shall return to this question of language shortly, but here it should be noted that while there is an invocation within this charter, there is no sanction or formal witness-list. Instead, it simply states that after the duration of the lease it would be against the pleasure of God ('ofer Godes est') if the land were to fall into the hands of someone other than the lord of the church ('pære circan hlaforde'). In addition, the draftsman names several of those present at the meeting within the main prose of the text, paying particular attention to the fact that Ealdorman Æthelred had organized the gathering with the gewitness and leaf of King Alfred. The impression, therefore, is of a relatively informal document, its draftsman not slavishly adhering to prescriptive rules of form.

The second such dispute memorandum reports events that occurred just one year later, in 897, relating to land at Upton in Blockley, Gloucestershire, which both the churches of Worcester and Winchcombe ostensibly were seeking to control. ${ }^{64}$ In language, form and focus, this document

For further discussion of the diplomatic of dispute memoranda in the earlier Anglo-Saxon period, see C. Cubitt, AngloSaxon Church Councils c.650-c.850 (London, 1995), esp. ch. 3.

${ }^{60} \mathrm{~S} 1441$ (Select English Historical Documents, ed. F. E. Harmer (Cambridge, 1914) [hereafter SEHD], no. 14). This charter has been preserved solely thanks to Liber Wigorniensis.

${ }^{61}$ This purportedly earlier diploma is $\mathrm{S} 103$.

${ }^{62} \mathrm{Cf}$. S 1457 , probably dating to the 980 s and similarly containing a rare reference to the testing of the bounds of the property. For discussion see Wormald, 'Charters, Law and the Settlement of Disputes', pp. 298-303; Insley, 'Archives and Lay Documentary Practice', p. 349.

${ }^{63} \mathrm{~S} 1432$ (AD 822x823) and 1437 (AD 825). Note that while neither of these documents survives in its original form, the orthography of both points towards an early date of composition. Of the two, S 1432 is the least problematic. See Gallagher, 'The Vernacular in Anglo-Saxon Charters', pp. 214-15.

${ }^{64} \mathrm{~S} 1442$ (BCS 575). This charter is preserved in both Liber Wigorniensis and the Nero-Middleton cartulary. 
is quite different to what we have just seen. Although similarly reported from a third person perspective, it is entirely in Latin. In addition, Wærferth does not receive a mention until near the very end of the text. Instead, the record begins with Ealdorman Æthelwulf, the brother of Ealhswith, King's Alfred's wife. Æthelwulf, we are told, was inspecting the hereditarii libri of his ancestor, the Mercian King Coenwulf (796-821), when he realized that the land in question at Upton should not be held by a leasing party for longer than one life, despite the fact that its current occupant, a man named Wullaf, had inherited control of the land from his father. The matter was brought before Ealdorman Æthelred, who judged that the documents in Wullaf's possession relating to the land must be handed over to Æthelwulf and, in return, Wullaf was permitted to keep the land for the duration of his life, on the condition that it then be passed to the church at Worcester. Again, therefore, we see leasing as part of the resolution of a dispute. At times the Latin prose of this document is frustratingly laconic, making elements of its story difficult to comprehend. Names are given in the main text with few other indicators as to the identities of the individuals, while it is not explicitly stated how this dispute undermined relations between the churches of Worcester and Winchcombe. Moreover, the role of Ealdorman Æthelwulf in all of this is unclear. Presented seemingly as an impartial agent, it must be borne in mind that the church at Winchcombe had an intimate history with Mercian royalty and thus, Æthelwulf, as a descendant of a Mercian king, may well have been acting on behalf of this religious community. ${ }^{65}$ It is notable, therefore, that Ealdorman Æthelred appears ultimately to have supported the case of Worcester rather than that supported by Æthelwulf, despite their connection through marriage (since Æthelred was married to King Alfred's daughter, Æthelflæd). Despite such ambiguities, the memorandum usefully makes an explicit reference to the nature of its own production, stating that it was drawn up in order that Wullaf may have a record of the agreement, and one imagines that it may have been produced in chirograph form, so that the Worcester community could keep a copy as well. ${ }^{66}$ Crucially, however, neither Wullaf nor Ealdorman Æthelred features in its witness-list. Instead, Bishop Wærferth is the first witness, followed by six individuals who are likely to have been members of the Worcester community. ${ }^{67}$ They are then followed by Ealdorman Ethelwulf and an additional eight individuals who are untitled in the version in Liber Wigorniensis, but four of which are named as ministri and one as a princeps in the Nero-Middleton cartulary. The final three names in the list, as it survives in the Nero-Middleton cartulary, are given the title matrona and are thus perhaps representatives from a nunnery at Winchcombe. ${ }^{68}$ The absence of Ealdorman \#thelred and Wullaf here, alongside the relative prominence of individuals from Worcester, is striking and may, therefore, indicate that this list represents not the gathering at which a resolution was sought, but rather a subsequent meeting at which the veracity of the written record was formerly verified by representatives of all interested parties - most likely after a Worcester draftsman had composed the main body of the charter.

\footnotetext{
${ }^{65}$ For further discussion of the connections between Winchcombe and Mercian royalty see S. R. Bassett, 'A Probable Mercian Royal Mausoleum at Winchcombe, Gloucestershire', The Antiquaries Journal 65 (1985), 82-100, esp. 84; M. A. Burghart, 'The Mercian Polity, 716-918' (unpubl. PhD dissertation, King's College London, 2007), pp. 259-60. See also Tinti, Sustaining Belief, p. 230. Note that Wormald succinctly summarizes this dispute as being 'between Wullaf, with Bishop Wærferth and the familia of Worcester, and Æthelwulf, dux, with the familia of Winchcombe': 'A Handlist of Anglo-Saxon Lawsuits', ASE 17 (1988), 247-81, repr. in and cited from his Legal Culture in the Early Medieval West, pp. 253-87, at 266.

${ }^{66}$ Lowe lists the following as examples of chirographs that explicitly record disputes or their settlements: S 1454 , 1460 and 1472. See Lowe, 'Lay Literacy', p. 173. All of these examples are considerably later than S 1442, though S 1281 demonstrates that chirographs were being issued at Worcester during Wærferth's episcopate at least for the production of episcopal leases; see the appendix below. Evidence for earlier chirograph production at Worcester is found in Humfrey Wanley's catalogue of 1705, which describes the now-lost single sheet of S 1273 (an episcopal lease issued in 855) as a chirograph; see Lowe, 'Lay Literacy', p. 188, no. 8.

${ }^{67}$ These individuals witness other Worcester charters from the time of Wærferth's episcopate. For example, the second individual in the witness-list, a priest named Beorhthun, also witnesses S 1415, 1416 and 1446; the fourth witness, a priest named Tidbald, also witnesses S 1415, 1416, 1279 and 1446.

${ }^{68}$ S. Foot, Veiled Women, 2 vols. (Aldershot, 2000) II, 239-40.
} 
Our third and final dispute memorandum dates to around the year 903 and concerns land at 'Sodbury', which is likely to be Old Sodbury in modern-day Gloucestershire. ${ }^{69}$ This was, as the record tells us, land to which several of Wærferth's predecessors had laid claim on behalf of Worcester, evidently without much success. As with the two earlier disputes, Wærferth brought this case to a meeting organized by Ealdorman Æthelred, at which the current occupant of the land, an otherwise unknown individual called Eadnoth, was also present. Unlike in our two earlier examples, however, Worcester was not necessarily the outright victor in this dispute: in return for a lump sum of forty mancuses and an annual fee of fifteen shillings, Eadnoth was permitted to keep the land in perpetuity and, as a result, Wærferth agreed to hand over the title deeds that related to the land. This outcome makes the document all the more interesting. The text is written entirely in the vernacular and does so - in contrast with the two earlier memoranda - for the most part from a first person perspective, through the voice of Wærferth ('ic Werferð...'). The Worcester community, meanwhile, dominates the witness-list, which comprises thirteen named individuals, the first being Wærferth and at least nine others being members of his church; notably, neither Æthelred, nor Æthelflæd, nor Eadnoth appears in the list. It is most likely, therefore, that this is a Worcester record and, whether or not the Worcester community was truly happy with the outcome of the dispute, it nonetheless is careful to place the agency with Wærferth. As to the other claimant, Eadnoth, we find him in a passage that precedes the blessing and the witness-list. Here we seemingly hear Eadnoth himself ('ic Eadnoð...'), who duly pledges to pay the annual charge to Worcester. Both this and the preceding sections spoken in the voice of Wærferth give the impression of a text capturing the public declarations that both sides made at the meeting of the Mercian witan. The witness-list, in contrast, makes no attempt to represent all those who were present when these pronouncements were made. Perhaps instead it reflects a second gathering, at Worcester, of individuals who confirmed the accuracy of the record once it had been written, much like we saw with the memoranda from 897.

Each of these three records gives us rare insights into the processes of Anglo-Saxon dispute resolution in the years immediately before and after AD 900 and it is possible to identify certain consistencies in their detail. For example, in each case, the venue for the discussion and resolution of the dispute was a meeting of the Mercian witan over which Ealdorman Æthelred presided, yet it is likely that all three documents were produced after this meeting by a Worcester draftsman. On two of these three occasions, furthermore, the written record appears to have been formerly attested after its production. There are, however, clear differences between these three documents in terms of their form and language. How can we explain these? It is possible that the choice of Latin for the memorandum of 897 may reflect the fact that this dispute was to a large extent concerned with the relationship between two ecclesiastical communities, although other individuals were also involved; the other two memoranda, both of which are in the vernacular, less obviously represent institutional battles. Yet arguably more important for explaining their form are the relationships that these three memoranda had with other contemporary documentation. Thus, it should be noted that following the resolution of the dispute of 896 , the Worcester community presumably continued to possess the related Latin title deed, a royal diploma of King Æthelbald. This may explain, therefore, the relative lack of formality of the associated memorandum, which lacks a witness-list and, indeed, is entirely in Old English. In the case of the dispute of 897, the Latin memorandum, which was formally attested, tells us that the community conversely handed over the original title deed to the other claimant. The third memorandum complicates this interpretation: it states that the other party now possessed the original title deed, which may explain the formal attestation of the memorandum, and yet this document is in the vernacular. It is perhaps significant, however, that this charter was composed in the early 900 s, at a time when the Worcester community was producing leases in Old English and the vernacular was thus perhaps being used with increasing frequency for documentary purposes.

\footnotetext{
${ }^{69} \mathrm{~S} 1446$ (SEHD 15). This charter survives only as part of Liber Wigorniensis. For discussion of 'Sodbury' see Tinti, Sustaining Belief, p. 110.
} 
Charters of the Mercian and West Saxon leaders

In addition to documents issued on behalf of the bishop and his community, the Worcester archive contains eight further charters dating to the episcopate of Wærferth that are likely to be substantially authentic. These were issued in the names of the West Saxon and Mercian leaders and are as follows:

Table 2: Charters in the Worcester archive issued in the names of the West Saxon and Mercian rulers during the episcopate of Wærferth

\begin{tabular}{cccc}
\hline \hline Sawyer & Date & Benefactor & Beneficiaries \\
\hline 215 & 875 & King Ceolwulf II & Bishop Wærferth \\
218 & 883 & Ealdorman Æthelred & $\begin{array}{c}\text { Berkeley Abbey; Cynulf; bishopric of } \\
\text { Worcester } \\
\text { minister Cuthulf }\end{array}$ \\
222 & $883 \times 911$ & Ealdorman Æthelred & Æthelwulf \\
223 & $884 \times 899$ & $\begin{array}{c}\text { Ealdorman Æthelred } \\
\text { and Æthelflæd } \\
\text { Ealdorman Æthelred }\end{array}$ & Church of St Peter, Worcester \\
346 & 887 & $\begin{array}{c}\text { King Alfred and } \\
\text { Ealdorman Æthelred } \\
\text { King Edward, } \\
\text { Ealdorman Æthelred } \\
\text { and Æthelflæd }\end{array}$ & Bishop Wærferth \\
& 889 & Wigferth
\end{tabular}

These eight charters are of immense historical value, particularly in shining light on the nature of the political concord between the West Saxon and Mercian leaders during the ascendency of the 'kingdom of the Anglo-Saxons' ${ }^{70}$ For present purposes, it is important to stress that not all of these charters were necessarily produced at Worcester. For one, as Simon Keynes has argued, a centralized agency within the royal household had begun to produce diplomas on behalf of the West Saxon kings from the mid-ninth century onwards, drawing up the charter quite possibly before a formal, highly ritualized conveyance ceremony at a royal assembly. ${ }^{71}$ The nature of contemporary Mercian royal diplomatic production, on the other hand, is quite uncertain, largely due to the extremely poor survival rate of charters from Mercian archives. It can be said at least that there is considerable stylistic variation amongst the small handful of surviving charters issued on behalf of Ealdorman Æthelred and Æthelflæd, making it unlikely that a single agency was responsible for their diplomatic output continuously and exclusively between the 880s and 910s.

Of the eight charters belonging to the Worcester archive, two examples are royal diplomas of which the beneficiaries are otherwise unknown individuals and there is no strong evidence to

\footnotetext{
${ }^{70}$ For discussion of the 'kingdom of the Anglo-Saxons' see Keynes, 'King Alfred and the Mercians', pp. 34-45; S. Keynes 'Edward, King of the Anglo-Saxons', Edward the Elder 899-924, ed. N. J. Higham and D. H. Hill (London, 2001), pp. 40-66, at 45-62.

${ }^{71}$ Keynes, 'The West Saxon Charters'; Keynes, 'Church Councils'.
} 
associate either with the Worcester scriptorium. ${ }^{72}$ The community at Worcester is a beneficiary of all six remaining documents and, in contrast, there is good reason to suspect that a Worcester draftsman produced at least some of them. The strongest candidate is perhaps the complex record of privileges and a lease that was issued in 883 on behalf of Ealdorman \#thelred. ${ }^{73}$ This opens with a grand proem citing the example of the Greeks that is otherwise found earlier only in charters from within the Worcester archive. ${ }^{74}$ Another of these documents, on the other hand, issued by Æthelred in 887, betrays influence from elsewhere. ${ }^{75}$ A grant of six hides to the bishopric of Worcester, this charter opens with an invocation and proem that closely resembles a formula found in three midninth-century West Saxon royal diplomas, ${ }^{76}$ while its sanction contains the grecism philarigia ('love of money'), which appears earlier in only one surviving Anglo-Saxon charter, a Mercian royal diploma of 848 from Breedon-on-the-Hill. ${ }^{77}$ This is not to discount outright this second example as a Worcester production, but it raises the possibility that draftsmen at Worcester could draw on diplomatic discourse from elsewhere, particularly if the agreement which they were recording involved parties from beyond their community. In this example from 887, it should be noted that King Alfred sits at the top of its witness-list.

The majority of these charters adheres to the conventional structure and language of an Anglo-Saxon royal diploma. Six are predominantly in Latin, while four of these six contain an Old English boundary clause. ${ }^{78}$ One also incorporates a vernacular list of serfs. ${ }^{79}$ The familiar appearance of most of these documents is a reminder that for all the diplomatic innovation and flexibility that we have so far seen at Wærferth's Worcester, there was a continuing demand for draftsmen, particularly those recording permanent donations of land, to maintain and replicate the traditional form of the Anglo-Saxon charter. The Latin diploma remained a powerful commodity in late ninth-century England. One specimen, which was issued in 889 to record a joint gift of land from King Alfred and Ealdorman Æthelred to the bishopric of Worcester, makes this point particularly clearly. ${ }^{80}$ The land in question, donated along with certain trading privileges, was a plot in the heart of the Roman city of London, which Alfred had re-established only three or so years earlier. This was evidently an exceedingly valuable and deeply symbolic gift, attesting to the importance and influence of the church of Worcester at this time. ${ }^{81}$ The document that records this donation, moreover, is the most spectacular and bombastic piece of Latin literature to survive from the Alfredian period, opening like so:

Sedulo namque nonnullis et maxime per instantis vitæ turbidam discordiæ rabiem . in hac decrepita finis mundialis canitiæ contingere solet quod simplicem memorialis præcordii

\footnotetext{
${ }^{72}$ S 219 (BCS 552) and 361 (BCS 607).

${ }^{73} \mathrm{~S} 218$ (SEHD 12). For comparison of the prose of this charter with Wærferth's Old English Dialogues, see D. Whitelock, 'Some Charters in the Name of King Alfred', in Saints, Scholars and Heroes: Studies in Medieval Culture in Honour of Charles W. Jones, ed. M. H. King and W. M. Stevens, 2 vols. (Ann Arbor, MI, 1979) I, 77-98, at 90; Bately, 'Old English Prose', pp. 133-4.

${ }^{74}$ Six earlier charters from the Worcester archive contain elements of S 218's proem, three of which include the reference to Greeks. These are S 1413, 148, 1262, 154, 193 and 1272. S 1413, 1262 and 154 contain the reference to Greeks, and the wording of S 1413 and 1262 is closest to that of the proem of S 218.

${ }^{75}$ S 217 (BCS 547).

76 These earlier West Saxon royal diplomas are S 300, 301 and 326.

${ }^{77}$ S 197 (Pet 8). See B. Snook, 'When Aldhelm Met the Vikings: Advanced Latinity in Ninth-Century Mercian Charters', Mediaevistik 26 (2013), 111-48, at 112-27.

${ }^{78}$ S 215, 222, 219, 217, 346 and 361. Of these, S 222, 219, 217 and 361 contain a vernacular boundary clause.

${ }^{79} \mathrm{~S} 217$. For the identification of these individuals as serfs and not slaves see D. A. E. Pelteret, 'Two Old English Lists of Serfs', Mediaeval Studies 48 (1986), 470-513, at 491-2; D. A. E. Pelteret, Slavery in Early Mediaeval England: from the Reign of Alfred Until the Twelfth Century, Studies in Anglo-Saxon History 7 (Woodbridge, 1995), 168-9.

${ }^{80} \mathrm{~S} 346$ (BCS 561). This charter is preserved only in Liber Wigorniensis.

${ }^{81}$ Another charter that attests to the relationship between Wærferth, London and the West Saxon and Mercian leaders is S 1628 (CantCC 100). This document purportedly dates to either 898 or 899 and records donations of land to Archbishop Plegmund and Bishop Wærferth. This charter is problematic in its surviving form and it is uncertain whether it records an additional donation to Wærferth or whether it is simply reiterating the agreement of S 346 . For discussion, see CantCC, pp. 833-6.
} 
oculum turbines obliviose obscenitatis quatientes reverberant ; seu nebulæ neglegentiarum nubiferis deprivationum fuscationibus ; a recte possessionis jure radiantem . justitiæ Phoebum obnubilant ${ }^{82}$

This document is entirely in Latin and its literary flair is quite unlike anything in the diplomatic corpus from Wærferth's episcopacy. We cannot be certain whether or not an individual from Worcester composed it, though a Worcester connection can at least be found in the sanction, which mistakenly refers to the biblical Ananias as 'Anna', an error that is found in only one other AngloSaxon charter - the aforementioned charter issued by Ealdorman Æthelred to the bishopric of Worcester just two years earlier. ${ }^{83}$ One should also note the apparent 'Aldhelmian' flavour of its prose, with its preponderance for alliteration, its unusual, polysyllabic vocabulary and its frequent use of hyperbaton, all of which somewhat anticipates the style of ' $Æ$ thelstan A'. ${ }^{84}$ It also aligns this charter nicely with the evidence of London, British Library, Royal 5. F. iii, a copy of Aldhelm's Prosa de uirginitate and one of very few surviving manuscripts for which a good case can be made for a late ninth-century Worcester provenance. ${ }^{85}$

Given the continuing importance of the Latin charter, it is even more remarkable when we find a document issued in the names of the Mercian and West Saxon leaders that diverges linguistically from the traditional form of an Anglo-Saxon royal diploma. Amongst the eight specimens in the Worcester archive, two do just that, both of which are highly likely to have been composed by Worcester draftsmen. First, we have the aforementioned record from 883 issued on behalf of Ealdorman Æthelred. ${ }^{86}$ This is in fact the earliest textual evidence for the governance of Mercia by Æthelred and it records a grant of privileges to Berkeley Abbey in exchange for land at Stoke Bishop, Gloucestershire, as well as the leasing of this same land for three generations to an otherwise unknown individual named Cynulf, son of Ceoluht. The charter states that after the duration of the lease, the land would be passed to the bishopric of Worcester. Although presented simply as a donation by Æthelred, the key to understanding this text is that it derives from an ongoing dispute between the churches at Worcester and Berkeley. Stoke Bishop lies very near to Westbury-on-Trym, an estate of immense value that would go on to be recorded in the eleventh century as the largest estate owned by the bishop of Worcester. ${ }^{87}$ Several documents in the Worcester archive attest to the church's long-running dispute with Berkeley over this land and its neighbouring estates, ${ }^{88}$ and this agreement in 883 , which was made at a meeting of the Mercian witan over which King Alfred presided, appears to be yet another attempt to reach a lasting settlement. On this occasion, the solution was a combination of privileges and leasing. As to its linguistic dynamics, this document is rather unusual. It opens with a Latin proem - borrowed, as we have already noted, from earlier Worcester diplomatic - but it then switches into Old English for the dispositive section, before returning to Latin for its dating clause and witness-list; it then concludes with a vernacular boundary clause. The bilingual nature of this document makes it particularly apt that its draftsman chose a proem that recalls the example of the Greeks, who were

\footnotetext{
82 BCS 561: 'For some men unremittingly and especially through the wild madness of the present life's discord in this feeble old age of the world's end, it is wont to come about that the shaking whirlwinds of oblivious obscenity batter the single eye of the heart's memory, or that the mists of neglect with darkening clouds of deprivations obscure the shining sun of justice from the rightful law of possession' (translation by Robert Gallagher).

${ }^{83} \mathrm{~S} 217$.

${ }^{84}$ For discussion of the prose style of 'Æthelstan A' see D. A. Woodman, " Æthelstan A" and the Rhetoric of Rule', ASE 42 (2013), 217-48; Snook, The Anglo-Saxon Chancery, pp. 86-124.

${ }^{85}$ For the 'Aldhelmian' features of S 346 see Snook, 'When Aldhelm Met the Vikings', pp. 129-30 and earlier scholarship cited there. For more on London, British Library, Royal 5. F. iii see above n. 12.

${ }^{86} \mathrm{~S} 218$. This charter survives in Liber Wigorniensis and with variations in the seventeenth-century transcriptions of Patrick Young (London, British Library, Cotton Vitellius C. ix).

${ }^{87}$ Tinti, Sustaining Belief, p. 24, n. 62.

${ }^{88}$ For discussion of this dispute and its charters see Wormald, 'Charters, Law and the Settlement of Disputes', pp. 2928; P. Wormald, How do we know so much about Anglo-Saxon Deerhurst?, (Deerhurst, 1993), repr. and cited from P. Wormald, The Times of Bede: Studies in Early English Christian Society and its Historian, ed. S. Baxter (Malden, MA, Oxford and Victoria, 2006), pp. 229-48, at 241-4; Tinti, Sustaining Belief, pp. 240-2.
} 
renowned for translating the Hebrew Bible into their own language; one is reminded here of a similar allusion to the Greeks in the preface to the Old English Pastoral Care. ${ }^{89}$ The incorporation of a Latin proem into an otherwise predominantly vernacular text, meanwhile, is reminiscent of the lease issued in favour of Ealdorman Æthelred and Æthelflæd in 904, and it no doubt reflects a similar desire to heighten the prestige of the document, which may, after all, have been issued at or following one of the earliest assemblies of the new political concord between Mercia and Wessex. The decision to compose the main body in the vernacular, however, is less easy to explain. As one would find in a royal diploma, the majority of the text is written as if spoken by the benefactor - in this case, Æthelred - yet to do so in Old English is to align this document more closely with the episcopal leases of the 900s and, most pertinently, those dispute memoranda that were composed in the vernacular, some of which also similarly speak from a first person perspective. One wonders here whether the unprecedented political circumstances of the early 880 s made it unsuitable to record a donation by Ealdorman Æthelred - especially one to which King Alfred was a witness entirely in Latin. ${ }^{90}$ Perhaps equally important - and arguably commensurate with the limited authority of Æthelred at this time - the charter does not record a permanent gift of land, that is, the creation of new bookland.

Similar variables are likely to be at play with the second linguistically unusual charter issued on behalf of the Mercian leader. Granted at an unknown date between 884 and 899 in the names of both Æthelred and Æthelflæd, this document records a gift of privileges within the newly fortified burh at Worcester to its ecclesiastical community, which would, in return, perform liturgical duties for the souls of their benefactors. ${ }^{91}$ The charter explicitly states that this agreement was made with the gewitness of King Alfred, although it does not survive with a witness-list. It also includes references to a series of specific dues (wagnscilling, seampending, landfeoh, wohceapung and burhwealles sceating), which were to be paid variously to King Alfred and the bishop of Worcester by the inhabitants of the burh. Moreover, the entirety of this document is in Old English, bar the titles of the two Psalms that are named within the description of liturgical obligations. The agreement that lies at the heart of this charter was evidently of the utmost importance to the relationships between the Mercian leaders, King Alfred and the church of Worcester. It should, therefore, be compared with the two documents that we have already met that respectively record the donation to Worcester of land at London that was issued in 889 (S 346), and the lease to Ealdorman Æthelred and Æthelflæd of a haga at Worcester in 904 (S 1280). In both of these other cases, however, the draftsmen drew on the prestige of Latin. The absence of Latin here is striking and in one respect it may reflect the fact that, in contrast to the lease of 904, the church was the recipient rather than the donor of the agreement; thus, seemingly, its draftsman did not feel compelled to open his document with a grand Latin invocation or proem. It may also be significant that this charter does not record the creation of new bookland, but rather a collection of specific legal dues, for which there may not have been direct Latin translations. Both the practical context in which such dues would have been summoned and the cultural associations between Latin, bookland and the Church may, therefore, have made the vernacular the logical choice of language for this document.

To sum up, a remarkable variety of material survives from Wærferth's Worcester, which collectively attests to a community that was evidently aware of the benefits of written documentation. There is considerable diversity in the form of the surviving specimens, indicative of a lack of standardized practice or, put in more positive terms, of a documentary culture that was at

\footnotetext{
${ }^{89}$ Old English Pastoral Care, ed. and transl. H. Sweet, EETS os 45 and 50 (London, 1871), 6-7.

${ }^{90}$ One should note here that in the 840 s a predominantly vernacular royal diploma was issued on behalf of the Mercian King Berhtwulf: S 204 (CantCC 75). This charter survives in its original form, but its place of production is unknown. It is the only Anglo-Saxon royal diploma surviving in its original form to have been produced in Old English. For discussion, see Gallagher, 'The Vernacular in Anglo-Saxon Charters', pp. 227-8 and 232. A diploma such as this could arguably have provided a precedent for the charter of S 218 , though our sense is that the tradition of writing royal diplomas in Latin would have had greater bearing on the linguistic decisions made by its draftsman.

${ }^{91}$ S 223 (SEHD 13). This charter survives solely thanks to Liber Wigorniensis.
} 
ease with flexibility in practice, allowing appropriate responses to the varying realities of specific situations. Within this context, draftsmen were able to compose prose in either Latin or the vernacular. As we have seen, the reasons for choosing to write in one or both of these languages on any given occasion were quite possibly multiple and varied. There is strong evidence to suggest that contemporaries associated Latin with prestige - a point that is perhaps unsurprising, but important to stress, given the weight of significance that has occasionally been placed on the use of the written vernacular in late ninth-century England.$^{92}$ Certain charters also suggest, more specifically, that in some diplomatic contexts Latin may have been reserved for the creation of new grants of bookland, while at other times this language was perhaps employed as a marker of ecclesiastical identity. In such circumstances, the vernacular thus acted as a valid alternative, allowing more selective use of Latin. It is not the case, therefore, that a draftsman necessarily composed any given charter solely due to related levels of literacy. Neither the relatively favourable standard of Latin in these charters nor the many variables that were evidently at stake when making a decision regarding language choice point towards such an interpretation. ${ }^{93}$

\section{DOCUMENTARY CULTURE BETWEEN W ÆRFERTH AND OSWALD}

For a period of almost fifty years between the end of Wærferth's episcopate and Oswald's accession to the see in 961, the Worcester archive has preserved just six royal diplomas, two episcopal grants and no dispute memoranda. Not only are these figures low, but several of the documents to which they refer are likely to be later forgeries.$^{94}$ Of the surviving episcopal charters - those documents that are most clearly products of the Worcester community - the earlier one (S 1289) was issued by Bishop Wilfrith in 922 and only survives in a seventeenth-century transcript made by William Hopkins $;{ }^{95}$ while the second (S 1290), a lease of Bishop Cenwald dated 957, was copied together with the later leases of Bishop Oswald into Liber Wigorniensis.

Wilfrith's charter is both interesting and problematic. First of all, by recording a perpetual grant of land at Clifford Chambers in Warwickshire for the community at Worcester, it represents the earliest extant grant of land made explicitly for the sustenance of the cathedral clergy. ${ }^{96}$ Moreover, it contains a case of code-switching which could be interpreted as an element of continuity with the practices of Wærferth's time. The text opens with a short proem and a dating

\footnotetext{
${ }^{92}$ See, for example, S. Foot, 'The Making of Angelcynn: English Identity before the Norman Conquest', TRHS 6th ser. 6 (1996), 25-49; K. Davis, 'National Writing in the Ninth Century: a Reminder for Postcolonial Thinking about the Nation', Journal of Medieval and Early Modern Studies 28 (1998), 611-37.

93 This is not to say that the standard of Latin within Worcester charters is remarkable, but they do (as they survive) compare favourably with the Latinity of documents from ninth-century Canterbury (on which, see M. Lapidge, 'Latin Learning in Ninth-Century England', in his Anglo-Latin Literature 600-899 (London, 1996), pp. 409-54). For evidence suggesting that Wærferth struggled in construing Latin prose in the making of the Old English Dialogues see M. Godden, 'Wærferth and King Alfred: the Fate of the Old English Dialogues', in Alfred the Wise: Studies in Honour of Janet Bately on the Occasion of her Sixty-Fifth Birthday, ed. J. Roberts and J. L. Nelson with M. Godden (Cambridge, 1997), pp. 35-51, at 44-7.

${ }^{94}$ The six royal diplomas are S 401, 402, 406, 428, 520 and 633, while the episcopal charters are S 1289 and 1290. The only reliable document among the royal diplomas is S 520, which is discussed further below. It has been demonstrated that the others are later forged texts which cannot cast light on the period between Wærferth and Oswald. For S 401, 402 and 428 see J. Barrow, 'The Chronology of Forgery Production at Worcester from $c .1000$ to the Early Twelfth Century', St Wulfstan and his World, ed. J. S. Barrow and N. P. Brooks (Aldershot, 2005), pp. 104-22, at 112-13; on S 406 and 633 see F. Tinti, 'From Episcopal Conception to Monastic Compilation: Hemming's Cartulary in Context', EME 11 (2002), 233-61, at 248-53.

${ }^{95}$ London, British Library, Harley 4660, 8r. It was printed by G. Hickes in G. Hickes and H. Wanley, Antiquae Literatura Septentrionalis Libri Duo (Oxford, 1703-5), I, 174-5. See Keynes, ‘Anglo-Saxon Charters', pp. 57-9.

${ }^{96}$ It should be noted that the boundary clause appended to this charter seems to describe the nearby parish of Milcote which was one of the estates disputed between the Worcester monastic community and that at Evesham in the eleventh century, as attested in Hemming's cartulary. Moreover, two hides at Clifford Chambers were also later leased out by Bishop Oswald to Withhelm, his minister, (S 1311), thus possibly superseding what had been established in Wilfrith's charter and perhaps also explaining why the latter was not copied into Liber Wigorniensis. See Tinti, Sustaining Belief, pp. 14-15, 197-8 and below, text corresponding to nn. 139-40.
} 
clause in Latin, before changing to Old English to provide a verbal invocation followed by the dispositive section:

Disponente regi regum cuncta cæli secreta nec non quæ sub cæli culmine apud homines notantur miro ordine gubernante cujus incarnationis humanæ anno dcccxxii indictione $\mathrm{x}$ hæc donatio quæ in ista cartula saxonicis sermonibus apparet confirmata ac donata erat. In usses dryhtnes noman hælendes cristes . Ic pilfrio biscop ...

The same opening Latin text, with minor variations, can also be found in a lease of Oswald of the year 990 (S 1363), surviving in both Liber Wigorniensis and the seventeenth-century manuscript which also preserves Wilfrith's charter:

Disponente regi regum [cunct]a cæli secreta nec non quæ sub cæli culmine aput homines mutantur miro ordine gubernante cujus incarnationis humanæ anno dcccexc Indictione iii. hæc donatio quæ in ista cartula saxonicis sermonibus apparet confirmata \& donata erat. In usses drihtnes noman hælendes cristes ic ospald erce bisceop ...97

These are the only two surviving Anglo-Saxon charters that make use of this Latin opening section, which interestingly flags the switch to the vernacular language ('saxonicis sermonibus'). The final words of the Latin text ('...hæc donatio quæ in ista cartula saxonicis sermonibus apparet confirmata ac donata erat') and especially its use of the past tense ('confirmata ac donata erat'), in contrast with the present tense ('ic sylle') employed in the main vernacular text of Wilfrith's charter, may be taken to indicate that the opening Latin section was added afterwards. However, it must be noted that the initial Latin passage is the only place in the charter where we find a dating clause. Thus, unless entirely fabricated, this clause cannot have been written long after the time of the recorded transaction. It is possible, in other words, that Wilfrith's document was initially redacted just in the vernacular and that a Latin proem and dating clause were added shortly afterwards, possibly on a second copy. ${ }^{98}$ This final redaction may, in turn, have inspired the draftsman of Oswald's later lease. Irrespective of whether the initial section formed part of the original document, it is striking that the dominant language of Wilfrith's charter should be Old English, even though it was issued by a bishop in favour of his cathedral community and even though it required the beneficiary to commemorate the anniversary of the bishop's death, thus evoking a liturgical context. ${ }^{99}$

\footnotetext{
97 These texts are edited and translated respectively as ASChart 21 and 64 . They have been here amended to reflect more closely William Hopkins's transcriptions in Harley 4660, 8r and 9r. The early eleventh-century copy of S 1363 survives in British Library, Cotton Tiberius A. xiii, 84v-85r. It matches very closely that in Harley 4660 as they both reproduce the cross at the beginning of the charter (i.e., its pictorial invocation) and the only noticeable variants include the use of $j$ instead of $i$ in the later version, as well as $a$ instead of $e$. It is also worth noticing that an $e$ was written above the $i$ in regi in the Harley 4660 version of S 1363, probably in order to make the text adopt the word's correct ablative ending.

${ }^{98}$ Here it is useful to note that amongst the charters listed by Sir William Dugdale in 1643 as being at Worcester (within what is now Oxford, Bodleian Library, Dugdale 12), he included on p. 506 a now lost 'carta Wilfrithi episcopi de terris in Ugginchalan' that, as Dugdale notes, contained both Latin and Old English (S 1840). Dugdale did not state what role either language played within the document nor did he provide a date for the charter, thus it could pertain either to the Bishop Wilfred who held the see between 718 and 745 or to the tenth-century Bishop Wilfrith. Given the presence of Old English, however, it is perhaps more likely to relate to a tenth-century context, in which the vernacular is found far more expansively in Anglo-Saxon charters than in the eighth century. Thus although there is no way of assessing the authenticity of S 1840, Dugdale's reference is nevertheless encouraging for viewing the Latin and Old English elements of S 1289 as part of the original document.

99 ' on condition that the remembrance of me in the sight of God be the more steadfastly observed among them. And every year also, by means of the estate, they shall commemorate to a certain extent the anniversary of my death with the profit which they obtain from the estate'. Translation from ASChart 21, p. 43. On charters containing arrangements for liturgical commemorations for beneficiaries see H. Foxhall Forbes, Heaven and Earth in Anglo-Saxon England: Theology and Society in an Age of Faith (Farnham, 2013), pp. 228-38.
} 
The other episcopal document which survives from this period is the above-mentioned lease of Bishop Cenwald of 957, issued in favour of Behstan, a priest of the Worcester community. ${ }^{100}$ This charter is, in contrast to that of Bishop Wilfrith, entirely in Latin. ${ }^{101}$ Several scholars have noted that it shares features with the alliterative royal diplomas issued in the 940s and 950s for which Cenwald has been suggested as the likely author. One of these alliterative charters, issued at Kingston-on-Thames in 946, was preserved in the Worcester archive before it went missing together with the other so-called 'Somers charters'. ${ }^{102}$ The lease and this alliterative royal diploma have various aspects in common, such as the opening reference to the grace of God ('concedente gratia Dei' in the diploma and 'gratia Dei suffragante' in the lease), the use of the third rather than the first person in the dispositive clause (a constant feature of the alliterative charters), and the use of the verb usurpare, which is not found in any earlier Worcester charters. ${ }^{103}$ An important point to note is that although Cenwald or someone in his closest entourage can probably be identified as the author of the alliterative charters, these diplomas should not be seen strictly as a product of the Worcester scriptorium; they may well have been drawn up at a royal assembly instead. At the same time, however, the alliterative charter preserved at Worcester is significant because it provides a link to the West Saxon centralized production of royal diplomas, which in this case probably relied on a Mercian draftsman who also happened to be the bishop of Worcester. Moreover, as has been noted by Simon Keynes, some of the vocabulary employed in the alliterative charters also appears in later Worcester episcopal leases, thus highlighting the importance of Cenwald's time at Worcester, in spite of the survival of only one document issued in his name. ${ }^{104}$

Possibly even more significant in this context is an apparently minor aspect of the alliterative charters, namely, their tendency to lapse into Old English in specific circumstances. This can be seen in particular in the way in which the royal style swiftly switches into the vernacular to refer to the peoples of the kingdom. In the case of the Worcester alliterative charter, code-switching is employed to describe the extent of King Edmund's former rule, now inherited by his successor, his brother Eadred. The text reads: 'Concedente gratia Dei anno dominicæ Incarnationis DCCCC . XLVI . contigit post obitum Eadmundi regis . qui regimina regnorum . Angulsaxna 7 Norphymbra . Paganorum . Brettonumque ... gubernabat' ${ }^{105}$ The Latin text thus incorporates the correct plural genitive Old English terms to refer to Edmund's control over the Anglo-Saxons and the Northumbrians, i.e., the two peoples among those listed who would have spoken the language

${ }^{100}$ S 1290 (BCS 993). This is a lease for four lives; the main land, the extent of which is not specified, is said to have been located in three places at Tapenhall in North Claines, Worcestershire, while a further hide was at an unidentified place called Grimanhyll, which could be Greenhill in Hallow, also in Worcestershire. See D. Hooke, Worcestershire Anglo-Saxon Charter-Bounds, Studies in Anglo-Saxon History 2 (Woodbridge, 1990), 149.

${ }^{101}$ One should note here the inclusion of S 1842 in the above-mentioned list of charters by Sir William Dugdale, described as 'carta Ceonuualdi de tribus mansis in Broctune Twa Thriddan 7 Stoce, anno domini DCCCCXLI' (Oxford, Bodleian Library, Dugdale 12, p. 502). The locations of the land prove that this was a different charter to S 1290. Dugdale noted that S 1842 was an entirely Latin document, just like S 1290, though Dugdale's own description of the charter also evidently contains Old English elements. Our thanks to Susan Kelly for her advice on this matter. ${ }^{102}$ S 520 (BCS 815). On the Somers charters see above at n. 51. Another alliterative royal diploma of King Eadwig is preserved in Hemming's cartulary (S 633) but appears to be spurious. See above n. 94.

${ }^{103}$ Cf. S 520 (BCS 815) and S 1290 (BCS 993). S 520 (BCS 815) also contains the noun usurpatio, which Ben Snook has identified as being typical of the alliterative charters' vocabulary: Snook, The Anglo-Saxon Chancery, p. 142 (though he omits S 520 from the relevant list). On the alliterative charters see also S. Keynes, The Diplomas of King Athelred 'the Unready': a Study in their Use as Historical Evidence, Cambridge Studies in Medieval Life and Thought 3rd ser. 13 (Cambridge, 1980), p. 82, n. 165; S. Keynes, 'King Æthelstan's Books', Learning and Literature in AngloSaxon England: Studies Presented to Peter Clemoes on the Occasion of his Sixty-fifth Birthday, ed. M. Lapidge and H. Gneuss (Cambridge, 1985), pp. 143-201 at 158-9, and Pet, pp. 228-29 with bibliography there cited.

${ }^{104}$ Keynes, 'King Æthelstan's Books', p. 159, n. 86.

105 BCS 815. See Pet, p. 229. For similar examples of code-switching see S 392 (though probably spurious), 473, 479, 544, 548, 549, 550, 569, 572 and 633. David Dumville has also suggested that $S 566$ (Pet 11) from the Peterborough archive may represent another production by the draftsman of the alliterative charters, though in this case the dominant language is Old English and Latin is only sporadically employed: D. N. Dumville, 'A Twelfth-Century English Translation of a Tenth-Century Latin Official Document?', Anglo-Saxon 1 (2007), 339-60, previously printed in Federov Readings / University Translation Studies 3 (2002 for 2001), 195-215. 
through which their ethnicity is named. A similar mixture of Latin and Old English can also be found in the witness-lists of a number of alliterative charters where code-switching seems to have been employed mostly in the interest of variety. ${ }^{106}$ In light of the frequent cases of code-switching which are attested in the later leases of Bishop Oswald, the precedents set by the alliterative royal diplomas, most likely drafted by Bishop Cenwald, must be borne in mind.

\section{BISHOP OSWALD'S TIME}

We turn now to the period of Oswald's episcopate itself, from which the Worcester archive has preserved six royal diplomas and as many as seventy-six episcopal leases, a unique and remarkably rich corpus of documentary sources which serves to highlight the importance that this type of land grant came to acquire at Worcester. In fact, although earlier generations, as we have seen, were clearly aware of the benefits of leasing, the frequency with which it occurred in Oswald's episcopate sets his documents apart. Different from the earlier period, furthermore, is the lack of dispute memoranda surviving from Oswald's episcopate. Insights into documentary practice in action can be gleaned, however, from a number of these episcopal leases, which contain detailed information about the context of the transaction, sometimes also providing precise instructions about subsequent heirs. For instance, one of Oswald's earliest leases established that after the first beneficiary's death, his mother, if she survived him, was to inherit the granted land, which had previously been held by another woman. ${ }^{107}$ Another early example, dated 963, contains an added note in Old English in which the first beneficiary declared that his first heir was going to be his son Æthelsige and that after the latter's death, the land could pass on to any heir of his choice, as long as the land remained on the male side of the family. ${ }^{108}$ A lease of the year 969 , meanwhile, in favour of Oswald's brother Osulf, contains a whole section about the land's inheritance, specifying that after the beneficiary's death, the estate had to go to whichever of his children survived longest; after their death, his wife Eadlifu was to succeed, and, in turn, she was to be succeeded by whichever two of her brothers she pleased, before the land reverted to the church of Worcester. ${ }^{109}$ Such detailed instructions about inheritance are likely to have been dictated by some tension among different family lines, and the leases can probably be seen as performing multiple functions in such cases, including the resolution or preemption of possible conflict, much like what we have seen from the time of Wærferth. ${ }^{110}$

As to the six royal diplomas from this period, three (S 726, 772 and 773) appear to be the work of one or other of the agencies which were in charge of charter production during Edgar's reign; they are unlikely, therefore, to be products of the Worcester scriptorium. ${ }^{11}$ A further two are

\footnotetext{
${ }^{106}$ Pet, p. 229. Both Latin and Old English are also employed in the witness-list of one of the charters from Wærferth's time (S 1280), as discussed above, text corresponding to nn. 47-8.

${ }^{107}$ S 1298 (BCS 1091).

${ }^{108}$ S 1303 (ASChart 35).

${ }^{109}$ S 1326 (BCS 1233).

${ }^{110}$ Similarly, S 1315 (BCS 1204), a lease of 967 also in favour of Osulf, involved a land exchange with the community at Worcester, an arrangement which was reiterated in 988 when the same lease was issued again in favour of Osulf's son (S 1355). Probable claims on the part of the cathedral monastic community also appear to emerge from S 1353 ( $\mathrm{J}$ M. Kemble, Codex Diplomaticus AEvi Saxonici, 6 vols. (London, 1839-48) [hereafter KCD], no. 660), which establishes that after the death of the second beneficiary the land must go to a member of the community before reverting to the episcopal see.

${ }^{111}$ The authenticity of S 772 (BCS 1229, surviving on single sheet as London, British Library, Add. Charter 19793) has been a matter of debate because of its palaeographical features. Its formulation is identical to that of S 773 (BCS 1234), in favour of the same beneficiary (Ælfwold, brother of Ealdorman Æthelwine) and also preserved until the eighteenth century in the Worcester archive. While some scholars have interpreted their shared language as the result of their having been issued on the same occasion, David Dumville has suggested that S 772 may have been forged at Worcester in the early eleventh century on the basis of S 773. See Dumville, English Caroline Script, pp. 70-3. It should be noted in any case that the evidence for the origin and development of Anglo-Caroline scripts at Worcester is complex and that there is no conclusive evidence for locating the origin of S 772 within that scriptorium. The church of Worcester never made any claim on either of the estates granted to Ælfwold through S 772 and 773 and the two diplomas did not make their way into any of the eleventh-century Worcester cartularies. Cyril Hart has interestingly suggested that $Æ l f w o l d ~$ might have deposited his diplomas at Worcester for secure keeping, also bearing in mind Oswald's special relationship
} 
obvious later forgeries (S 731 and 788). The final diploma (S 751), meanwhile, is problematic: it may contain a section which was added at Worcester, but it is not clear when exactly this may have happened, given that the document has only been preserved in the late eleventh-century Hemming's cartulary. ${ }^{112}$

Chiefly, what this material collectively indicates is that by Oswald's time the output of the Worcester scriptorium was in several ways different from that of Wærferth's. The typology of documents that were being produced had shrunk, mostly because the consolidation of the West Saxon dynasty and the concurrent unification of the English kingdom had led to a situation in which a church like that of Worcester would not have been required to play the role in the production of royal diplomatic that it is likely to have played when Æthelred and Æthelflæd were ruling in Mercia. At the same time, however, the total amount of charters produced in the second half of the tenth century is much higher than what we have for Wærferth's episcopate, indicating that as well as being more specialized, Worcester draftsmen also became more prolific in terms of documentary output.

\section{Oswald's episcopal leases}

The seventy-six leases which survive from Oswald's episcopate represent the culmination of a tradition and practice which, as we have already seen, had started much earlier at Worcester. ${ }^{113}$ Oswald's leases date from between 962 and 991, thus covering his entire episcopate. They are distributed throughout this period with just a couple of significant gaps, in the years $963-5$, and 970-3. ${ }^{114}$ As to the beneficiaries, they cover categories similar to those represented in earlier leases, comprising relatives of the bishop, members of the cathedral community and, above all, lay people who are described through such words as minister, cniht, and amicus. Interestingly, none of these leases was issued in favour of Oswald himself, in contrast to what we have seen with Wærferth, who issued two such leases of land to himself. Considering, however, that Oswald granted several leases to members of his family, including his brothers Osulf and Æthelstan, and that, as Vanessa King has shown, the total hidage of land granted to his kin amounts to nearly a quarter of all the land he leased out, both bishops evidently took direct measures to make sure that portions of the church of Worcester's land remained within their respective families for a number of generations. ${ }^{115}$

While aspects such as the distribution of the land leased and the status of Oswald's beneficiaries have been studied by several generations of scholars, the extremely interesting

with his brother Æthelwine, founding benefactor of Ramsey, and the fact that Ælfwold himself was the recipient of a lease of land from Oswald in 962 (S 1298). See C. Hart, The Early Charters of Northern England and the North Midlands (Leicester, 1975), pp. 81-2. On Ælfwold see D. Bullough, 'St Oswald: Monk, Bishop and Archbishop', St Oswald of Worcester, ed. Brooks and Cubitt, pp. 1-22, at 11.

112 BCS 1201.

${ }^{113}$ It should also be noted that the tradition would continue after Oswald, as attested by the survival of sixteen further episcopal leases issued in the period beginning with the episcopate of Bishop Ealdwulf (992-1002) and ending with the close of Bishop Ealdred's rule at Worcester (1046-62). The earliest of these (S 1381) was copied into Liber Wigorniensis; another (S 1408) is only preserved in Hemming's cartulary, while six (S 1385, 1399, 1393, 1394,1407 and 1405) survive as single sheets. The remaining eight are known thanks to the transcriptions which were made between the seventeenth and eighteenth century: two (S 1384 and 1406) were copied by William Hopkins into Harley 4660, while the other six (S 1388, 1392, 1395, 1396, 1397 and 1409) are part of the group of now lost Somers charters. For more on the Somers charters see above, n. 51. We should also state at the start of this section that the document entitled Indiculum libertatis (S 1368, BCS 1136), contained in Hemming's cartulary and purporting to be a letter written by Bishop Oswald to King Edgar to explain the nature of his leases, will not be taken into account here, since the document is most likely to have been forged for inclusion in the late eleventh-century cartulary in order to reinforce Worcester's claims on its lost estates; see V. H. Galbraith, 'Notes on the Career of Samson, Bishop of Worcester (10961112)', EHR 2 (1967), 86-101, at 100-1 and Barrow, 'The Chronology of Forgery Production', pp. 115-16, but cf. P. Wormald, 'Oswaldslow: an Immunity?', St Oswald of Worcester, ed. Brooks and Cubit, pp. 117-28, at 118-19. For a discussion of the Indiculum which bears in mind its manuscript context see Tinti, 'From Episcopal Conception to Monastic Compilation', pp. 244-7.

${ }^{114}$ See Keynes, Atlas, Table LXXVI.

${ }^{115}$ V. King, 'St Oswald's Tenants', St Oswald of Worcester, ed. Brooks and Cubitt, pp. 100-16, at 111. 
linguistic features of these documents have only recently started to attract significant attention. ${ }^{116}$ As detailed in Table 3 below, out of seventy-six surviving leases, seventeen are entirely in Latin, sixteen have the main text in Latin but employ the vernacular for the boundary clause, five are entirely in Old English, while as many as thirty-eight make use of both languages in the main body of the text. ${ }^{117}$

Table 3: Language use in Oswald's leases

\begin{tabular}{|c|c|c|}
\hline Language & Sawyer & Description \\
\hline \multirow[t]{3}{*}{ Latin } & $\begin{array}{c}1298,1302,1328, \\
1331,1333,1341, \\
1343,1344,1345, \\
1349,1354,1357 \\
1359,1360,1364, \\
1365,1308\end{array}$ & Latin only \\
\hline & $\begin{array}{c}1301,1306,1323, \\
1325,1330,1335, \\
1340,1348,1346, \\
1351,1361,1353, \\
1356\end{array}$ & Latin with Old English bounds \\
\hline & $1319,1321,1329$ & $\begin{array}{l}\text { Latin with Old English bounds, } \\
\text { appurtenances and/or summary of } \\
\text { witnesses }\end{array}$ \\
\hline Old English & $\begin{array}{c}1309,1326,1332 \\
1362,1366\end{array}$ & Old English only \\
\hline Mixed & $\begin{array}{c}1300,1307,1297, \\
1303,1304,1310, \\
1311,1314,1315, \\
1312,1313,1370, \\
1316,1317,1318, \\
1322,1320,1327, \\
1324,1336,1334, \\
1337,1338,1339, \\
1342,1347,1350, \\
1352,1367,1355, \\
1358,1363\end{array}$ & $\begin{array}{l}\text { Both Latin and Old English are used in } \\
\text { the main text, though Latin would seem } \\
\text { to be the dominant language }\end{array}$ \\
\hline
\end{tabular}

\footnotetext{
${ }^{116}$ See H. Schendl, 'Beyond Boundaries: Code-Switching in the Leases of Oswald Worcester', Code-Switching in Early English, ed. H. Schendl and L. Wright (Berlin, 2011), pp. 47-94, and Tinti, 'Writing Latin and Old English'.

117 In several respects this last figure represents a conservative estimate. For instance, the sanctions of three of the charters which have been considered as entirely Old English (S 1309, 1326 and 1332) open with Latin invocations to Saints Mary, Michael and Peter ('Sancta Maria 7 sanctus Michael cum sancto Petro'). While the presence of Latin here is undeniable, we have considered it too minimal to classify the language of the charters as 'mixed'. This was done also bearing in mind that saints' names (and the preceding adjectives sanctus/sancta) are generally declined as Latin when appearing in the nominative in otherwise Old English texts, as is the case here for Mary and Michael; for further discussion see Tinti, 'Writing Latin and Old English', p. 325, and below, text corresponding to nn. 141-7. The difficulties inherent in trying to provide a clear-cut classification of the leases' language is highly indicative of the ease with which draftsmen could switch from one language to the other while composing these charters. It should also be noted that Table 3 does not take into account the languages employed in the witness-lists, which would make the picture even more varied.
} 

seem to be the dominant language

In some of the thirty-eight mixed-language charters it is difficult to determine which of the two languages is dominant. A particularly illuminating example is provided by $\mathrm{S} 1310$, which switches from Latin to Old English in the middle of the dispositive clause, before switching back to Latin again at the end of the same clause:

Ego Oswold . largiflua dei clementia antistites . Quandam rusculi partem .III. silicet mansas tribus tamen in locis diuisam cui uocabulum est . æt Eanulfestune . oper healf hid 7 æt Uferan Strætforda on pære gesyndredan hide pone operne æcer 7 æt Fachanleage pone priddan æcer feldlandes . 7 healfne pone wudu on easthealfe pæs weges 7 pone æt pære

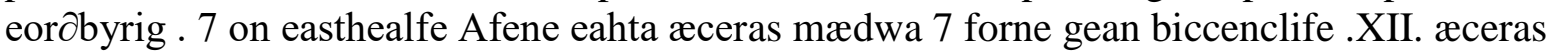
mædwa 7 preo æcras benordan Afene to myllnstealle . EADRICO . meo compatri . æternaliter concessi . et post uitę suę terminum duorum derelinquat cleronomo eorumque uitę finito curriculo ad usum primatis in Wiogornaceastre redeat immunis. ${ }^{118}$

In contrast to Wærferth's documents, Oswald's texts do not show any possible chronological progression towards the use of one or the other of the two languages, and those documents which are predominantly in Old English are distributed throughout the entirety of the period. ${ }^{119}$ Moreover, vernacular charters appear to have been issued in favour of different categories of beneficiaries, including both lay people and members of the cathedral community; in other words the decision to employ Old English cannot simply be linked to the beneficiaries' presumed lack of understanding of Latin, as has been suggested, for instance, for the charters which survive from ninth-century Canterbury. ${ }^{120}$ Perhaps even more interestingly, it can be demonstrated that different charters in favour of the same beneficiary make use of different languages or varying combinations of the two. For example, the cleric named Wulfgar, who received half of the grants issued in favour of members of the Worcester community, is the recipient of an almost entirely vernacular lease and of three more such grants whose main opening dispositive clauses are in Latin, but which also contain other sections in Old English. ${ }^{121}$ The three leases in favour of the above-mentioned brother of Oswald named Osulf also vary noticeably in this respect: the first is predominantly in Latin but also contains a vernacular sanction; a second one is entirely in Old English (and, incidentally, survives as a single sheet); while a third one, which is undated but may be, like the previous one, of the year 969, provides several instances of code-switching, including both a Latin and a vernacular sanction. ${ }^{122}$ It would seem, therefore, either that language choice was not determined by the needs of the beneficiaries, or that the linguistic preferences of beneficiaries (and draftsmen) varied according to different situations and circumstances.

Remarkably, most of Oswald's leases belong to one of a set number of formulaic models that were available - and most likely developed - at Worcester throughout his pontificate. ${ }^{123}$ This is especially apparent in the case of texts whose dominant language is Latin (or, at least, whose

\footnotetext{
118 ASChart 43.

119 The earliest lease whose main text is almost entirely in Old English is S 1299 (ASChart 34), which dates to 962, the first year of Oswald's pontificate, while the last one, S 1366 (KCD 676), is dated 991.

${ }^{120}$ Three predominantly vernacular leases were issued in favour of members of the Worcester community: S 1372 (KCD 682), 1374 (KCD 681) and 1369 (KCD 683). On Canterbury see Brooks, 'Latin and Old English' and CantCC, pp. 123-32, but cf. Gittos, 'The Audience for Old English Texts'.

${ }^{121} \mathrm{~S} 1372$ (KCD 682) is the almost entirely vernacular charter. Of those which have the dispositive clause in Latin, S 1327 (BCS 1240) contains vernacular descriptions of appurtenances and bounds; S 1342 (KCD 627) has a vernacular date, sanction and boundaries; while S 1352 (KCD 649) has both a summary and the boundary clause in Old English.

122 These are, respectively, S 1315 (BCS 1204), 1326 (BCS 1233) and 1370 (BCS 1139).

${ }^{123}$ For full discussion of these models see Tinti, 'Writing Latin and Old English'.
} 
dispositive clauses are in Latin). These can be divided into ten different groups, each comprising between two and sixteen leases that employ virtually identical wording from one another up until the end of the dispositive clause. A similar, though smaller and less fixed set of formulaic models can be identified for the leases which are mostly in Old English. The availability of different sets of stock formulae increases the number of choices that the leases' drafters could make when writing such documents: it was not just a question of which of the two languages to use for each of the component sections of the charter but also which of the various available formulations to adopt. The emergence of these different typologies should probably be interpreted as the outcome of the intense lease production which characterizes Oswald's time at Worcester. In other words, it should not come as a surprise that instead of having seventy-six completely different texts, the majority of them should correspond to models that were used at least twice and, in one case, as many as sixteen times. ${ }^{124}$ What is more difficult to understand is the rationale for choosing one model over the others. One possible explanation could be the existence of different draftsmen with specific preferences for one or more of the available typologies. Unfortunately, however, since we only have two surviving single sheets, each representing different typologies of leases and different linguistic choices, such a hypothesis cannot be tested palaeographically. Some elements may nevertheless point in that direction. In a couple of cases we can observe the existence of pairs of charters issued in the same year with identical features, except, of course, the name of the beneficiary and the name and extent of the estate. The witness-lists also match perfectly. ${ }^{125}$ It is tempting to read behind each of these identical pairs the hand of one draftsman who chose to employ a given model for two charters issued on the same occasion.

The importance of the availability of such sets of models is confirmed by the strikingly different features of the only one of these episcopal leases which did not originate at Worcester. This is a lease of 973 issued by Oswald in the course of an assembly summoned by King Edgar in London. It is worth dwelling briefly on this charter because of the unusual circumstances in which it was issued. The document does not contain a list of names of the cathedral community's members, since they would not have followed Oswald to London for the assembly. Instead its text ends with the following sentence: 'Hoc uero actum est sub prefati regis testimonio . Dunstanique archipresulis . atque Ælfhere ducis . reliquorum etiam tam episcoporum quam nobilium attestatione uirorum'. ${ }^{26}$ The circumstances of this lease of five hides of land in Oxfordshire in favour of a man called Brihtric are clearly different from those of all the other leases issued by Oswald, as this grant is said to have been made with the witness of the king, the archbishop of Canterbury, the earl of the Mercians and several other bishops and noblemen. ${ }^{127}$ It is no surprise, therefore, that this text should not match any of the models that a scribe would have had at his disposal in the Worcester scriptorium in 973. No other lease from this year survives, but it can be observed that this was the only charter of Oswald among those issued in the 970s not to belong to any of the above-mentioned typologies. Furthermore, unlike all the other leases issued by the same bishop, it is written in the third person, reinforcing the impression that this document was not produced by the usual procedures that were in place at Worcester. Indeed, one imagines that Oswald conveyed the general

\footnotetext{
124 The chronological distribution of the various sets of formulaic models suggests an initial phase of experimentation with relatively limited repetition of the same models throughout the 960 s, followed by a second phase - between the late 960 s and the late 970 s - dominated by the consolidation of a limited number of models which are used more frequently, and a last phase in which the initial models cease being used and the drafting of the charters becomes less dependent on sets of stock formulae. See Tinti, 'Writing Latin and Old English'.

${ }^{125}$ These features can be observed for S 1337 (KCD 620) and 1338 (KCD 619) of the year 978 and also for two undated Old English leases likely to have been issued in 978/9: S 1372 (ASChart 58) and 1374 (ASChart 57). See Keynes, Atlas, Table LXXVI.

${ }^{126}$ S 1328 (BCS 1293).

${ }^{127}$ One would obviously like to know more about Brihtric's identity and status, the nature of his relationship with Oswald and the reasons that made the latter decide to grant this specific portion of land while attending an assembly in London. It is interesting to note that the five hides of land granted were attached to a larger episcopal estate at Pyrton and that Oswald did not need to ask for his community's permission in order to lease out land which had probably already been set aside for the use of the bishop. See Tinti, Sustaining Belief, pp. 212-13.
} 
sense of what he wanted his document to say to whoever was available to write it, either someone within his entourage or perhaps even a royal scribe. The final result is a short Latin text providing just the essential information, with no detail about the characteristics of the estate, let alone a boundary clause. It seems likely, moreover, that the choice of Latin for this lease was reflective of a context in which the influence of royal diplomas would have been more palpable. ${ }^{128}$

Beyond the importance of a set of available models for the creation of these documents, not much more can be said about the practical aspects of the production of Oswald's leases at Worcester. Anecdotal information, such as that describing the cathedral clergy's attesting of a document in Bishop Wærferth's bur, cannot be found in Oswald's charters. Nor do the extrinsic features of the two surviving single sheets suggest that the attestations could have been added at a later stage of production. That said, one of the surviving single sheets (S 1347) would seem to indicate that the place-name of the estate leased was not initially available to the scribe and that the boundary clause was added on the dorse of the charter after horizontal folding. ${ }^{129}$ It would seem, therefore, that a multi-stage production could occur if and when specific information on the estate was not initially available to the scribe.

The earliest emerging sets of formulae stopped being employed in Oswald's leases in the early to mid-980s, at a time when we see the concurrent emergence of more freely constructed charters that do not belong to any of the models identified and which begin to incorporate invocations and proems more frequently. ${ }^{130}$ The Latin of the later leases also appears to be on average more elaborate than that of the leases issued in the earlier phases of Oswald's pontificate. All of this may be explained bearing in mind the natural turnover in the cathedral community composition, one which did not involve any abrupt substitution of secular clerics with reformed monks, as was the case at Winchester, but which, rather, led to a more gradual transformation of the cathedral chapter into a monastic community. ${ }^{131}$ These later draftsmen may well have been influenced by the ideals and fashions of the reform movement. As we noted at the opening of our discussion, Worcester did not produce any of the most representative authors of the reform and only a small number of surviving manuscripts can be associated with the cathedral community from this time. ${ }^{132}$ It is thus difficult to be specific about what kind of cultural, literary or linguistic developments the reform may have brought about there. At the very least, however, the more elaborate Latin leases of the second half of Oswald's pontificate, including the more frequent employment of proems and invocations and the less slavish reproduction of established models, appear to have been the result of advancements in Latin learning. ${ }^{133}$ Some of these later leases employ alliteration and polysyllabic, rather Aldhelmian words, not dissimilar to the flamboyant prose of the diploma issued to Bishop Wærferth in 889 (S 346) and, perhaps more significantly, comparable with the stylistic features of several texts that are closely associated with the monastic reforms. ${ }^{134}$ Oswald himself seems to have selected Greek-based vocabulary for his attestations,

\footnotetext{
128 Three reliable diplomas of King Edgar dated 973 have survived (S 790, 791 and 793), but it is not possible to establish whether any of these were issued at the same London assembly where Oswald's lease originated. See S. Keynes, 'A Conspectus of the Charters of King Edgar, 957-75', Edgar, King of the English, 959-975: New Interpretations, ed. D. Scragg, Publications of the Manchester Centre for Anglo-Saxon Studies 8 (Woodbridge, 2008), $60-80$, at 74.

${ }^{129}$ This single sheet is reproduced here as Figures $3 \mathrm{a}$ and $3 \mathrm{~b}$. For a more detailed discussion of its materiality see the Appendix below.

130 Tinti, 'Writing Latin and Old English'.

${ }^{131}$ See above, n. 19.

132 No Latin writing attributed to Oswald survives either, although we know that he was a student of the Frankish scholar Frithegod in Archbishop Oda's household and that he studied at Fleury for some years: M. Lapidge, 'Schools, Learning and Literature in Tenth-Century England', Settimane di studio del Centro italiano di studi sull'alto medioevo 38 (1991), 951-98, repr. in and cited from his Anglo-Latin Literature 900-1066 (London, 1993), pp. 1-48, at 31.

${ }^{133}$ A late tenth-century Latin grammar of Canterbury origin may have reached Worcester soon after it was written: Gameson, 'Book Production', p. 233.

${ }^{134}$ See, for instance, S 1341 (KCD 625: dapsilitas), 1344 (KCD 634: clandestinus, paraclitus, onoma, pristinus) and 1308 (BCS 1167: panton, conditor, propatulus, conamen, paradigma). For further discussion of S 346 see above, text pertaining to $\mathrm{nn}$. 80-5. On the Latin style generally associated with the tenth-century monastic reform see M. Lapidge,
} 
being described as ecclesiarches in one lease (a word which afterwards is found in only one surviving Anglo-Saxon charter, a Worcester document of 1017 issued by Archbishop Wulfstan) and as catascopus in a royal diploma of Edgar whose list of attestations was most likely composed by the bishop himself. ${ }^{135}$ Together, this evidence is a reminder that Latin clearly played an important role in the production of Oswald's leases both quantitatively, as indicated by Table 3 above, and qualitatively. On many occasions, in other words, it remained important for episcopal documentation at Worcester to contain Latin. In several respects this is probably to be interpreted as the result of the continuing influence of royal diplomas as models for the drafting of episcopal documents, in a context within which Latin could have been perceived as the principal language of documentary culture. ${ }^{136}$

The leases of Oswald also demonstrate that Old English could be used confidently for a number of different functions. Leases written entirely in the vernacular were issued throughout the period under investigation, thus continuing a practice which had already started in Wærferth's time with the issue of two Old English leases. ${ }^{137}$ In addition, in examples that include Latin (which is most), switches into the vernacular are particularly frequent when draftsmen need to describe appurtenances or provide details about tenurial arrangements, as well as, of course, boundary clauses. Yet in other cases, the employment of the vernacular - for purposes such as the invocation and the introduction of the witness-lists - clearly demonstrates that its role went well beyond the provision of technical details which would have been difficult to describe in Latin. It should be noted here that although the earlier of Oswald's documents do not contain invocations, both Latin and Old English examples can be found in his later episcopal leases. In this respect, therefore, it can be maintained that it was the nature of the lease as a type of charter-text which evolved in Oswald's time, rather than a change in the function of one or the other language.

What is specific to Old English in the leases issued in Oswald's time is the introduction of a new section which is not to be found in earlier texts and which, for want of a better word, we have called the 'summary'. Vernacular summaries are included in seventeen leases whose predominant language is in most cases Latin. ${ }^{138}$ They always appear after the dispositive clause but can precede other component sections such as the dating clause or the request for payment of dues or service. The earliest examples are from the very beginning of Oswald's episcopate - an innovation perhaps introduced at the behest of the new bishop - while the latest instances are from the mid-980s. In most cases these short passages provide a brief recap of the essential information contained in the main text of the charter: the name of the beneficiary, the extent of the land leased, its location, and the duration of the grant; but in some other examples they also add technical details and descriptive information which had not found a place in the main text or could not presumably be properly supplied in Latin. For instance, the summary provided for a lease of two mansae of land at Clifford Chambers in Warwickshire issued by Oswald in 966 for Wihthelm, his minister, reads:

Đonne is pæs landes ealles pe Ospald biscop bocað pihtelme his pegne on pa ge rad pyrce $\mathrm{p}[\mathfrak{x t}]$ he pyrce $\mathrm{p}[\mathfrak{x t}] \mathrm{b}[\mathfrak{x t}]$ land sy un for porht into pære halgan stope preora manna dæg oper healf hid ge dal landes 7 healf hid on pære ege. ${ }^{139}$

\footnotetext{
'The Hermeneutic Style in Tenth-Century Anglo-Latin Literature', ASE 4 (1975), 67-111, repr. in his Anglo-Latin Literature, pp. 105-49; M. Lapidge, 'Poeticism in Pre-Conquest Anglo-Latin Prose', Aspects of the Language of Latin Prose, ed. T. Reinhardt, M. Lapidge and J. N. Adams, PBA 129 (Oxford, 2005), 321-37; R. Stephenson, 'Scapegoating the Secular Clergy: the Hermeneutic Style as a Form of Monastic Self-definition', ASE 38 (2009), 101-35; Stephenson, The Politics of Language, pp. 14-19.

${ }^{135}$ S 1341 (KCD 625), 1384 (KCD 1313) and 690 (Abing 87). On Oswald's possible participation in the drafting of S 690 see M. Lapidge, 'Æthelwold as Scholar and Teacher', Bishop AEthelwold: His Career and Influence, ed. B. Yorke (Woodbridge, 1988), pp. 89-117, repr. in and cited from his Anglo-Latin Literature, pp. 183-211, at 186-7.

${ }^{136}$ For examples of direct influence from contemporary royal diplomas, especially the so-called 'Edgar A' charters, on the formulation of Oswald's leases see Tinti, 'Writing Latin and Old English'.

${ }^{137}$ S 1283 (ASChart 16) and S 1281 (ASChart 18).

${ }^{138}$ S 1300, 1299, 1307, 1297, 1304, 1305, 1310, 1311, 1314, 1316, 1370, 1318, 1336, 1334, 1347, 1350 and 1352.

${ }^{139}$ S 1311 (BCS 1181).
} 
While the first part of the summary simply outlines in Old English what the main text of the lease has in Latin, the final words specify that the estate consisted of 'one and a half hides of shareland and half a hide on the island'. ${ }^{140}$ The occurrence of passages of this type in texts whose predominant language is normally - though not exclusively - Latin would seem to provide further evidence for the more pragmatic and functional role that Old English could possess in these documents. Indeed, the vernacular was no doubt the obvious choice of language for a part of the charter that was seemingly developed as a quick and convenient overview of its contents.

Another salient feature of Oswald's leases, however, points towards a more performative, less practical function for Old English in these documents, namely the vernacular sanction which appears in nineteen documents issued between 966 and $988 .{ }^{141}$ Although details vary from case to case, most of these sanctions share the same features, including their opening in Latin with an invocation to the saints Mary, Michael and Peter. An example is provided by one of the leases issued in favour of Oswald's brother, Osulf, a text which would have been entirely in Latin, but for the inclusion of this sanction:

Sancta Maria 7 sanctus Michael cum sancto Petro 7 allum Godes halgum gemiltsien ðis haldendum gif hpa butan gepyrhtum hit abrecan pille God hine to ryhtere bote gecerre . gif he ðonne nelle hæbbe him pið God gemæne on ðam ytemestan dæge ðyses lifes . ${ }^{142}$

While the sanctions of Oswald's leases have been analysed in detail elsewhere, ${ }^{143}$ here it is worth pointing out two aspects: first, the different nature and function of the Old English employed in these passages, especially when compared with the aforementioned summaries; second, the combined use of Latin and vernacular in the initial, positive section of the sanction, also known as the blessing. Language choice here becomes a complex and multifaceted issue. One might be tempted to argue that by departing from the more common employment of Latin for sanctions in contemporary royal diplomas, the draftsmen of these leases were consciously choosing to use a language which was closer to and more easily understood by all the parties involved in the transactions. ${ }^{144}$ In this case, however, the choice of everybody's language was not due to the need to provide practical or technical details about tenurial arrangements, but was made to invoke saintly protection on those who upheld what was established in the leases and, conversely, to warn potential transgressors of the spiritual punishments they would encounter, especially on the Last Day. ${ }^{145}$ Spiritual sanctions of this kind have attracted attention for the light they cast on ritual curses

\footnotetext{
${ }^{140}$ For more examples of summaries in Oswald's leases and for further discussion of their possible origin and function see Tinti, 'Writing Latin and Old English'.

${ }^{141} \mathrm{Ibid}$. Of these nineteen documents, eleven have their dispositive clause in Latin. An earlier case of a vernacular sanction from the Worcester archive is provided by S 218 (SEHD 12), which may have inspired the later developments of Oswald's time. It is also worth noting that Latin sanctions only appear in five leases of Oswald.

${ }^{142}$ S 1315 (BCS 1204): 'May St Mary and St Michael with St Peter and all the saints of God be merciful upon those who uphold this. If anyone, without due cause, attempts to break it, may God turn him to due amendment. If he will not do this, he shall have to account for it to God on the last day of this life' [translation adapted from Schendl, 'Beyond Boundaries', p. 65].

143 Tinti, 'Writing Latin and Old English'.

${ }^{144}$ Vernacular sanctions can also be found in other, both earlier and contemporary, private charters written entirely in Old English; see S 1197 (a mid-ninth-century bequest from Canterbury), S 1483 (a mid-tenth-century will from Bury St Edmunds) and S 1449 (a record of the adjustment of the boundaries between the monasteries in Winchester from the 970s).

${ }^{145}$ Incidentally, it can also be noted that while the leases' sanctions cover some of the semantic areas which have allowed for the identification of the so-called Winchester vocabulary, the Worcester leases do not seem to employ any of the words which characterize such a vocabulary. On Winchester vocabulary see H. Gneuss, 'The Origin of Standard Old English and Æthelwold's School at Winchester', ASE 1 (1972), 63-83; W. Hofstetter, 'Winchester and the Standardization of Old English Vocabulary', ASE 17 (1988), 139-61, and M. Gretsch, 'Winchester Vocabulary and Standard Old English: the Vernacular in Late Anglo-Saxon England', Bulletin of the John Rylands Library 83 (2001), 41-87. Speaking generally, Godden has remarked that 'Winchester vocabulary does not ... seem to have been used in Worcester': 'Wærferth and King Alfred', p. 44.
} 
and the eschatological culture of late Anglo-Saxon England. ${ }^{146}$ They also illuminate the performative function of charters, which in the case of these leases becomes even more interesting because of the intrasentential code-switching in the opening portion of the sanction; this provides further evidence for the ease with which the scribes at Worcester could make the two languages interact, not just to deal with agricultural organization or estate management, but also to convey the legal, eschatological and semi-liturgical nature of the leases' sanctions. A particularly intriguing example is $\mathrm{S} 1315$, the sanction of which, as noted above, is the only part of the document to contain any Old English. ${ }^{147}$ It was at this overtly eschatological moment in the charter - and not when describing more technical aspects of the agreement, as one might expect - that it was decided to convey information in the vernacular.

\section{CONCLUSION}

Viewing the charters of Worcester over the span of a century allows us to garner a sense of modes of practice, with all their developments and idiosyncrasies, that would be more difficult to appreciate if one was to focus solely on, say, the charters of Wærferth's episcopate. This broader perspective makes clear that variety in language choice was a persistent feature of documentary practice at Worcester over the course of the tenth century, though it was manifest in differing ways across the generations. Arguably most striking is the frequency and prominence of code-switching within many of Oswald's leases, in a manner that would probably have appeared strange to Wærferth and his draftsmen. Indeed, while the late ninth- and early tenth-century charters similarly attest to the choice that was available to draftsmen to write in either Latin or Old English, there is relatively little bilingualism present within any one example, and very few examples of intrasentential code-switching. Contrast can also be found in terms of typologies: while we see considerable variety in the forms and functions of documents being produced at Worcester during Wærferth's time, draftsmen there in the later tenth century, though extremely prolific, appear to have been more specialized in their work. First and foremost they were engines for the production of episcopal leases, for which they drew on a series of models that betray a level of systemization that is not apparent in earlier decades.

Such differences raise important questions about the developing nature of documentary practice at Worcester throughout the tenth century. What variables were most significant in accounting for these changes? What do they tell us about the production and function of written records within this community? And what do they reveal about attitudes there towards Latin and the vernacular? In all respects, the relationship with the production of royal diplomatic needs to be borne in mind. The development of a royal chancery undoubtedly had a considerable impact on the nature of documentary production at Worcester, as well as at other ecclesiastical centres. With the introduction of a royal writing office, draftsmen at Worcester would have been less likely to be called upon to facilitate royal communication; or when they did - as with the probable case of Bishop Cenwald - it would have been amidst the milieu of royal assemblies. Such a process helps to explain the limited variety of documents that survive from Oswald's time, while it also means that his draftsmen are less likely to have produced episcopal documents at the same time as royal diplomas. In terms of language choice, the association between Latin and the latter type of charter at times was potentially extremely influential. We have suggested that in the production of a given document, the presence and use of royal diplomas within the same context may explain the decision to write predominantly in either Latin or the vernacular - though not necessarily with the same outcome. In some cases, such as the dispute memorandum of 897, the absence of a royal diploma may have compelled those responsible for this document to write in Latin. Conversely, the lease of

\footnotetext{
${ }^{146}$ Petra Hoffman has noted that spiritual sanctions become particularly numerous in royal diplomas of the second half of the tenth century: 'Infernal Imagery in Anglo-Saxon Charters' (unpubl. PhD dissertation, University of St Andrews, 2008), p. 31 and bibliography cited there.

147 This is also the case for S 1355, the text of which was essentially lifted from that of S 1315 when, in 988, Oswald reissued for his nephew Ælfwine the three-life lease of land that he had first granted to his brother Osulf (Ælfwine’s father).
} 
973 recording an agreement made at a royal assembly in London is entirely in Latin quite possibly because it derives from a context with which one would associate royal (Latin) diplomatic. From another perspective, the possible influence of royal diplomatic may also be seen in the intrasentential code-switching of the alliterative diplomas: documents that were quite possibly composed by Bishop Cenwald, which somewhat anticipate - and perhaps legitimized - the use of bilingualism in Oswald's leases. Moreover, the general association between Latin and royal diplomas - those records representing probably the oldest and, indeed, a majority of charters within the possession of Worcester up to the time of Oswald's accession - arguably would have perpetuated a sense of Latin as the 'traditional' language of documentary culture. This may go some way to explaining the inclusion of Latin within many of Oswald's leases.

It must be stressed that the relationship with royal diplomatic is but one of numerous factors that could influence the use of Latin and Old English in any one charter. For instance, it is possible for the material from the time of Wærferth that an association between Latin and ecclesiastical identity may have been influential as well; the same cannot be said of the documents from Oswald's episcopate. Above all, we have sought to stress that throughout the entirety of this period language choice was not simply a reflection of literacy levels. Customary precedent, diplomatic models and the function and performance of the document could all be as important, if not more so, and such variables worked together and against each other within the specific context of a given charter's production. Collectively the evidence of this material forcefully supports the interpretation that language choice was highly sensitive to multiple contextually defined variables.

The remarkable linguistic dynamics of this corpus, furthermore, represent an important dimension to thinking about how documents were both produced and used at Worcester. The late ninth- and early tenth-century charters, as we have seen, provide rare anecdotal insights into the specific circumstances in which written records were issued and utilized, for which comparative material from Oswald's time is sorely lacking. The witness-lists of Oswald's leases do nevertheless suggest that these documents were produced in what seem to have been rather private circumstances, since the only witnesses named are members of the cathedral community. ${ }^{148} \mathrm{We}$ can only imagine whether or not these leases were similarly confirmed within the bishop's bur, as at least one of Wærferth's leases was, but the possibility of such procedures is a reminder of the performative contexts in which these documents functioned - and with this in mind, the linguistic dimension to these records becomes all the more interesting. As we have noted, the use of Old English invocations appears to have been an innovation of Wærferth's community; in the leases of Oswald, meanwhile, we find examples of vernacular invocations and sanctions. The use of Old English for such spiritual matters is striking and hints at the potential with which the Worcester community instilled their vernacular tongue. ${ }^{149}$

How, then, should we understand these charters in a wider context? It is beyond question that the material from tenth-century Worcester is exceptional within the surviving Anglo-Saxon diplomatic corpus. ${ }^{150}$ Where the debate may lie is in assessing how these records would compare

\footnotetext{
148 Oswald's leases are so formulaic in the introduction of the witness-lists that they do not give away any detail on the circumstances of the grant itself or the phases in which the text was written. Cf Waerferth's lease above, especially the discussion pertaining to $\mathrm{nn}$. 51-7.

${ }^{149}$ Potentially fruitful comparison here may be made with, amongst other places, the tenth-century religious community at Chester-le-Street, which similarly embraced both Latin and the vernacular in their literary and spiritual activity. For discussion see K. L. Jolly, The Community of St Cuthbert in the Late Tenth Century: the Chester-le-Street Additions to Durham Cathedral Library A.IV.19 (Columbus, OH, 2012).

${ }^{150}$ It is worth noting that the sixteen later Worcester episcopal leases mentioned above at n. 113 appear to confirm the main trends established in the tenth century. Latin is the dominant language in all but three cases (S 1399, 1394 and 1406). Code-switching within the main text, i.e., beyond the predictable inclusion of vernacular bounds, occurs in six charters (S 1381, 1385, 1388, 1399, 1393 and 1405), including one intrasentential case (S 1388). Vernacular summaries are included in two mainly Latin texts (S 1381 and 1405), while Old English sanctions feature in two of the predominantly vernacular leases (S 1394 and 1406). In other words, what survives from the eleventh century indicates that interest in language choice remained strong at Worcester, but also confirms that the tenth century was truly exceptional both in quantitative and qualitative terms.
} 
with the documentary output of other ecclesiastical centres, if other archives had preserved such large numbers of tenth-century episcopal documents. Is the exceptional status of this material simply a reflection of the activities of the eleventh-century cartularists, which were, on their own terms, undeniably extraordinary? Or is there more to it? Perhaps the most obvious point of comparison is the Christ Church, Canterbury archive, in which an equally large and rich body of material is preserved, including a wealth of predominantly vernacular ninth-century records that survive as original single sheets. As we have noted, the content of this archive differs from what we have seen from Worcester in several ways. Not only does much of this Canterbury documentation survive in contemporary forms, but there is only one surviving episcopal lease; instead, much of this archive - other than royal diplomas - comprises wills, dispute memoranda and records of lay grants of land. Old English material, meanwhile, is found earlier on than at Worcester but with far less frequency in the tenth century than it occurs in Oswald's leases; furthermore, it is rare amongst the Canterbury records to find intrasentential code-switching. Elsewhere, ninth- and tenth-century material issued in the names of ecclesiastics survives in relatively small numbers, with the Old and New Minster archives at Winchester collectively preserving the most numerous examples, including several episcopal leases. The earliest of these Winchester episcopal leases, which dates to the 870s, contains a short Latin invocation ('in nomine domini'), while the attestations begin with 'ego' and feature several Latin titles; yet this charter is predominantly in Old English, like almost all later ecclesiastical charters from Winchester. ${ }^{151}$ It thus provides an important point of comparison with the developments of Wærferth's episcopate. Neither this nor later Winchester leases, however, exhibit the levels of code-switching found in Oswald's leases. In other words, what we have seen at Worcester should not necessarily be taken as indicative of wider Anglo-Saxon documentary culture. Despite the contacts between religious communities and between individual ecclesiastics, practices varied, which may have extended specifically to the ways in which Latin and the vernacular were employed.

Finally, what can the dynamics of documentary culture at Worcester tell us about late Anglo-Saxon literary culture more generally? Charters stood very much at the interface of the ecclesiastical and the secular, with documentary production representing a distinctive mode of interaction between religious communities and wider society. Charters also would have been one of the most frequent and tangible ways in which many lay individuals interacted with the written word. Thus, this material offers an exceptional opportunity to garner a sense of the character of AngloSaxon literate society at its most inclusive. With this in mind, the importance of the performative, ritualistic and visual qualities of the written word are evident to see in these charters, as it is in the contents of other archives. The linguistically distinctive features of the Worcester corpus, furthermore, are an important witness to the comfort with which contemporaries employed both Latin and Old English within these contexts. Susan Kelly succinctly described this phenomenon, particularly in relation to the leases of Oswald, as a form of 'casual bilingualism', ${ }^{152}$ which problematizes the explicit statements of authors such as Byrhtferth of Ramsey, who drew clear distinctions between the worlds of Latin and vernacular learning, ${ }^{153}$ and it offers a stark contrast to the view provided by the palaeographical evidence of many tenth- and eleventh-century charters and manuscripts, in which the two languages were commonly distinguished by script. ${ }^{154}$ Indeed, this evidence supports the recent work of Elaine Treharne and Helen Gittos, among others, who

${ }^{151} \mathrm{~S} 1275$ (ASChart 14). This is preserved in the Old Minster archive alongside two later episcopal leases, S 1287 and 1285. S 1287 (dating to between 879 and 908) is entirely in Old English, while S 1285 (dated 902) opens with a Latin invocation ('in nomine domini') but otherwise is also in Old English. Comparably, two ecclesiastical leases survive in the New Minster archive, S 1417 and 1420. S 1417, issued between 924 and 933 by the familia of the New Minster, is entirely in Latin, while S 1420, issued on behalf of the abbot and community of the New Minster between 995 and 1005 , opens with 'in nomine domini' but is otherwise in the vernacular.

152 Kelly, 'Anglo-Saxon Lay Society', p. 50.

${ }^{153}$ Stephenson, The Politics of Language, esp. ch. 2; Gittos, 'The Audience for Old English Texts'.

${ }^{154}$ Dumville, English Caroline Script, pp. 18-29 and 152-4; J. Crick, 'English Vernacular Script', in The Cambridge History of the Book in Britain, ed. Gameson, pp. 174-86, at 180-1. Not all manuscripts, however, consistently respected the script differentiation between the two languages; see Stephenson, The Politics of Language, pp. 50-5. 
have argued convincingly that writers in late Anglo-Saxon England were fervent users of their own language not due to limited Latinity, but because Old English had authority and legitimacy in its own right. ${ }^{155}$ The charters of Worcester demonstrate that Old English could function in the same way as Latin, that the two languages were to an extent and in some contexts interchangeable with one another. Yet these records also remind us that despite the wide-ranging functions of the vernacular as a written medium, Latin remained important; relatively few of Oswald's leases, after all, are entirely in Old English. The story of Anglo-Saxon England's bilingual literary culture, in other words, is one of nuance and complexity, and this is made no clearer than with the documentary corpus from Worcester.

\section{APPENDIX}

\section{The surviving tenth-century Worcester single-sheet charters}

There are only three surviving original single sheets from the period spanning the time of Wærferth and Oswald's episcopates that are likely to be products of Worcester scribes. All three are episcopal leases and they deserve special attention for the exceptional evidence that they provide for the production and materiality of documentary culture, as well as the attitudes towards Latin and Old English within related contexts. For these reasons, we offer a brief overview and discussion of these three single sheets.

The earliest of the three is S 1281 (London, British Library, Add. Charter 19791), which dates to 904. Images of its face and dorse are printed here as Figures 1a and 1b. This lease is entirely in the vernacular and was issued in favour of a reeve named Wulfsige, providing one hide of land at Aston Magna, Gloucestershire. It is a modest 20/1 cm x $16 \mathrm{~cm}$ (7cm x 5cm when folded) and it is evidently the lower half of a chirograph, since the word 'CYROGRAPHVM' sits at the top of the parchment, the top half of its letters having been lost with the cutting of the parchment into two. This surviving copy is presumably the half that was retained by the church at Worcester, which was responsible for the production of the document and which gave the upper half to the beneficiary for his own keeping. An eighteenth-century transcription of a now lost single sheet makes clear that at least one other of Wærferth's leases was produced as a chirograph, ${ }^{156}$ and in fact it is quite possible that all episcopal leases - and some other forms of documentation - were drawn up at Worcester in this form during Wærferth's episcopate. ${ }^{157}$ This lease was copied out by a single hand, writing in a slender and compact Insular minuscule with particularly elongated descenders. The script is easily legible but not especially calligraphic. ${ }^{158}$ Following immediately below

'CYROGRAPHVM', the text spreads over fifteen lines and makes use of almost all of the face of the parchment. The last six lines, which make up the witness-list, are noticeably more compressed (presumably because the scribe was concerned about space), though the scribe made no intentional visual distinctions between the constituent parts of the charter, unlike in the two later tenth-century Worcester single sheets. ${ }^{159}$ Moreover, there is no clear evidence to indicate multiple stages of production. That said, it is worth noting that the shapes of the crosses in the witness-list, which

\footnotetext{
155 Treharne, 'The Authority of English'; Gittos, 'The Audience for Old English Texts'.

${ }^{156} \mathrm{~S} 1283$ (ASChart 16). This is one of the lost 'Somers' charters. For details, see above, n. 51.

157 Tinti, Sustaining Belief, p. 12. For further discussion of the chirograph form see Lowe, 'Lay Literacy'. It should also be noted that the earliest surviving Anglo-Saxon single-sheet charter that was certainly a chirograph (S 221) dates to just three years earlier than S 1281 and is preserved in the archive of another ecclesiastical community in Mercia, Much Wenlock.

${ }^{158}$ Our thanks to Colleen Curran and Christine Voth for palaeographic advice. For further comments on the script of the lease see D. N. Dumville, 'English Square Minuscule Script: the Background and Earliest Phases', ASE 16 (1987), 14779, at 157, n. 52; D. N. Dumville, Wessex and England from Alfred to Edgar: Six Essays on Political, Cultural and Ecclesiastical Revival, Studies in Anglo-Saxon History 3 (Woodbridge, 1992), 92, n. 182; S. D. Thompson, AngloSaxon Royal Diplomas: a Palaeography, Publications of the Manchester Centre for Anglo-Saxon Studies 6

(Woodbridge, 2006), 70.

159 Tinti, Sustaining Belief, p. 77.
} 
precede the names of each witness, vary considerably, as does the spacing between the crosses and the corresponding names. It is tempting to imagine the crosses, therefore, as autographed signs, added either while or after the scribe wrote the names of the witnesses, much as may have been done with the production of the 'alliterative charters' of Bishop Cenwald's time. ${ }^{160}$ A final point to make concerns the dorse, which contains three sets of medieval endorsements, two of which are later than the original text of the lease. The third endorsement, however, looks to be contemporary, perhaps also being the work of the main scribe. It sits neatly within one of the squares formed by the folds of the charter and was evidently, therefore, added after folding. It simply reads 'Wulfsiges lond boc', allowing quick identification of the charter after it had been stored away. Such a function for an endorsement is not unusual - several comparable examples can, for instance, be found amongst the ninth-century single sheets from Christ Church, Canterbury - though the means of identification, solely by the name of the beneficiary, is exceptional; it is far more common to find a charter endorsed in reference to the estate to which it relates. ${ }^{161}$

The two other surviving single sheets from our period are both leases of Bishop Oswald: $\mathrm{S}$ 1326 and 1347. Images of both can be seen at Figures 2a, 2b, 3a and 3b. The earlier one (London, British Library, Add. Charter 19792) is dated 969 and is entirely in Old English; it was issued in favour of Osulf, Oswald's brother, who is here referred to as his kinsman, and it pertains to land at Teddington and Alstone in Gloucestershire. ${ }^{162}$ The later single sheet (London, British Library, Add. Charter 19794), of AD 984, is a lease of two and a half hides at Caldinccotan in favour of a minister called Cynelm. While the later of the two is, like Wærferth's single sheet, the bottom part of a chirograph, the earlier of Oswald's single sheets represents the upper half of such a document, thus suggesting that there were no specific rules as to the portion that the church of Worcester would have retained. In both of Oswald's leases, meanwhile, the spelling of the word for chirograph is slightly different from that which sits at the top of Wærferth's lease, as in the two later specimens it reads 'CYROGRAVVM' instead of 'CYROGRAPHVM'. This may be the result of phonological transfer from Old English, which had voiced [v] in intervocalic positions; since Old English speakers would have found it difficult to pronounce medial voiceless [f], the spelling in Oswald's leases may give us an idea of how this Latin word was pronounced in Anglo-Saxon England. ${ }^{163}$ Both of the two later parchments are wider than the earlier one, resulting in a more rectangular shape than that of Wærferth's charter. S 1326 measures $28.2 \mathrm{~cm}$ x $16.6 \mathrm{~cm}$, while S 1347 measures $30 \mathrm{~cm} \times 15.2 \mathrm{~cm}$. Although they remain smaller than contemporary royal diplomas, their shape, layout and further extrinsic features certainly point towards more explicit influence from royal charters than we find with Wærferth's lease. ${ }^{164}$

In the case of S 1326, visual similarities with royal diplomas include the pictorial invocation that opens the text, as well as the layout of the final attestations, which are organized into five columns, listing the members of the Worcester community in hierarchical order, with the 'masspriests' preceding the clerics in lower orders. Each of these names is duly preceded by a cross, as is also the case for Oswald's subscription, which can be found on the last line of the main text, separated by a small blank space from its final two words. ${ }^{165}$ The layout of the witness-list and the space left between the crosses and the names do not seem to indicate different phases of

\footnotetext{
${ }^{160}$ Keynes, 'Church Councils', pp. 94 and 166.

${ }^{161}$ For further discussion of endorsement practices see R. Gallagher and K. Wiles, 'The Endorsement Practices of Anglo-Saxon England', in The Languages of Early Medieval Charters: Latin, Germanic Vernaculars and the Written Word, ed. R. Gallagher, E. Roberts and F. Tinti (Leiden, forthcoming).

162 The text says that Oswald issued the lease in favour of Osulf 'for uncre sibbe': ASChart 46.

${ }^{163}$ We are grateful to Olga Timofeeva for this suggestion.

${ }^{164}$ Comparing the shape of Wærferth's lease with that of contemporary royal diplomas is not as straightforward as it is for Oswald's documents because very few survive; however, an interesting point of comparison is provided by S 221, a grant of the year 901 issued by Æthelred and Æthelflæd, leaders of the Mercians, in favour of the community at Much Wenlock. The surviving single sheet (London, British Library, Cotton Charter viii. 27) is certainly larger and markedly more rectangular than $\mathrm{S} 1281$.

${ }^{165}$ This reads 'Her is seo hondseten Oswoldes bisceopes 7 unna pæs hierdes on Wiogernaceastre' ('Here is the signature of Bishop Oswald and the permission of the community at Worcester'), thus also introducing the following attestations.
} 
composition, though it is worth noticing that the shapes of the crosses for Oswald and Wulfric, the first priest on the list, are different from those of the following other witnesses, most probably so as to point out the attestations of the bishop and the head of the community. ${ }^{166}$ The script of S 1326 is Square minuscule, of a type which leans towards conservative insular features. ${ }^{167}$ Although the charter does not employ any display script, it is interesting that the beginning of the sanction should be flagged through the employment of slightly larger letter-forms for the eight words which make up its opening Latin invocation ('Sancta Maria 7 sanctus Michahel cum sancto Petro'). The capital initial ' $S$ ' of the word 'Sancta' is especially remarkable, since it is bigger than any other letter in the text. The overall effect is one which gives special prominence to the only Latin words employed in this single sheet, thus highlighting the scribe's awareness of the importance of the code-switching at this specific point in the charter.

The later surviving single sheet of Oswald, S 1347, shows both elements of continuity and change. The layout and overall organization of the text are similar to those of S 1326: it opens with a chrismon and the attestations are grouped into four columns which list the members of the community in a hierarchical order, from Oswald (by this time, archbishop) through the priests, the deacons and, finally, the clerics in lower orders. ${ }^{168}$ The text would seem to have been mostly written in only one stage with the exception of the place-name indicating the location of the estate ('æt Caldinccotan'), which was probably added by the same scribe in a second stage of production, as the space that he had initially left blank did not prove to be sufficient for the number of letters he had to insert, to the effect that the final part of the place-name had to be inserted in the interlinear space between the ending of the fourth line and the beginning of the fifth. Though in terms of general layout similarities between the two surviving single sheets of Oswald can be easily identified, important differences also exist, mainly due to the different linguistic choices made by their respective scribes. The dominant language of the later lease is in fact Latin, written in a variety of Style I English Caroline minuscule, as defined by T. A. M. Bishop, which looks less rounded and more compressed than better known specimens of the same script. ${ }^{169}$ The Latin main portion of the text employs display script for the names of Oswald, the king, the ealdorman of Mercia and the beneficiary of the lease. The document also incorporates an Old English 'summary' between the main Latin text and the list of attestations. In this case, differently from S 1326, the switch of language is clearly flagged through the use of a new script, as the vernacular 'summary' is written in Anglo-Saxon minuscule; in the case of S 1326 the change in language is only marked by a slight change in script size. ${ }^{170}$ In S 1347 size also plays a more important role, since the vernacular letterforms are notably smaller than those of the main Latin text. The extrinsic features of the two Oswald leases would thus seem to reinforce the significance of the linguistic choices made by their scribes; in the earlier case the brief switch to Latin occurs at the beginning of the sanction and is flagged through the employment of an initial substantial capital S followed by the use of a script which is still Square minuscule, though the letter-forms are slightly bigger than those of the preceding vernacular text. In the later case the order is inverted but the effect is similar: a larger main Latin script followed by smaller vernacular letter-forms. Though the change of the size of the letter-forms in the earlier lease is not as dramatic as in the later one, both charters end up giving more prominence to the Latin portions of their respective texts. It should also be noted that on the dorse of S 1347 we find a vernacular boundary clause of the estate leased, which was added after

\footnotetext{
166 On Wulfric see Tinti, Sustaining Belief, pp. 30, 68 and 69.

${ }^{167}$ According to Neil Ker this would be the last dated text to employ horned 'a' (Ker, Catalogue, p. xxviii), while David Dumville has referred to the script of this charter as an example of the ways in which 'insular traditions reasserted themselves by the end of the 960s' after a period in which Square minuscule had adopted some Caroline letter-forms: Dumville, English Caroline Script, pp. 152-53.

${ }^{168}$ Differently from the earlier two single sheets, each name in the list of attestations is in this case preceded by the word 'ego'.

${ }^{169}$ See T. A. M. Bishop, English Caroline Minuscule (Oxford, 1971), p. xxii; Dumville, English Caroline Script, pp. 75-76.

${ }^{170} \mathrm{Ker}$, Catalogue, p. xxvi. On the visual distinctions generated by the contemporary use of two different scripts and the significance of their being drawn along linguistic lines see most recently Crick, 'English Vernacular Script'.
} 
horizontal folding. The hand appears to be the same as the one on the face, though it is interesting that the script is even smaller than that of the vernacular summary. Size of script was, therefore, clearly meant to indicate a hierarchy within the various component parts of a charter, much like we see in contemporary royal diplomas with the juxtaposition of main text and boundary clause. ${ }^{171}$

[INSERT Figure 1a]

Caption: The face of S 1281, a lease Bishop Wærferth dating to 904 (London, British Library, Add. Charter 19791, reproduced with the kind permission of the British Library Board)

[INSERT Figure 1b]

Caption: The dorse of S 1281, a lease Bishop Wærferth dating to 904 (London, British Library, Add. Charter 19791, reproduced with the kind permission of the British Library Board)

[INSERT Figure 2a]

Caption: The face of S 1326, a lease Bishop Oswald dating to 969 (London, British Library, Add. Charter 19792, reproduced with the kind permission of the British Library Board)

[INSERT Figure 2b]

Caption: The dorse of S 1326, a lease Bishop Oswald dating to 969 (London, British Library, Add. Charter 19792, reproduced with the kind permission of the British Library Board)

[INSERT Figure 3a]

Caption: The face of S 1347, a lease Bishop Oswald dating to 984 (London, British Library, Add. Charter 19794, reproduced with the kind permission of the British Library Board)

[INSERT Figure 3b]

Caption: The dorse of S 1347, a lease Bishop Oswald dating to 984 (London, British Library, Add. Charter 19794, reproduced with the kind permission of the British Library Board)

\footnotetext{
${ }^{171}$ This article is part of the research activities conducted by the Grupo de Investigación GIU17/006, funded by the University of the Basque Country, the Spanish Ministerio de Economía, Industria y Competitividad (HAR 2014-51484ERC and HAR2017-86502-P) and IKERBASQUE, Basque Foundation for Science. For further information on our work on the languages of early medieval charters visit our website at www.ehu.eus/lemc. Additional funding for the completion of this article has been provided by a Leverhulme Trust Early Career Fellowship.
} 